\title{
PERANAN MASYARAKAT LOKAL DALAM PERENCANAAN RUANG KAWASAN PERMUKIMAN KABUPATEN TEMANGGUNG
}

\author{
Su Ritohardoyo ${ }^{1}$ dan Agung Jauhari ${ }^{1}$. \\ ${ }^{1)}$ Fakultas Geografi Universitas Gadjah Mada Yogyakarta \\ Email: surito@ugm.ac.id
}

\begin{abstract}
ABSTRAK
Makalah ini menyajikan hasil penelitian tentang (1) pengetahuan masyarakat dan pelaksanaan RTRW; (2) peran serta masyarakat dalam pelaksanaan $R T R W$ dan pengendalian pemanfaatan ruang dalam pelaksanaan RTRW; (3) hak masyarakat dalam pemanfaatan ruang. Penelitian dilakukan di Kecamatan Temanggung menggunakan metode penelitian survei, dan pengumpulan data dari 80 rumahtangga responden, yang dipilih secara acak sederhana. Data diolah menggunakan teknik skoring untuk kuantifikasi data kualitatif. Analisis dilakukan secara kualitatif deskriptif maupun kuantitatif.Hasil penelitian menunjukkan bahwa masyarakat di Kawasan Pusat Perkotaan memiliki kondisi sosial ekonomi (rerata pendapatan) lebih baik daripada masyarakat di Kawasan Perkotaan Pinggiran. Namun demikian pengetahuan masyarakat tentang RTRW dan pelaksanaan $R T R W$ relatif sama yakni pada tingkat rendah, karena belum adanya sosialisasi dari pemerintah. Peranserta masyarakat dalam melaksanakan kewajiban pada RTRW dan pengendalian pemanfaatan ruang dalam pelaksanaan RTRW masih relatif rendah. Hak pemanfaatan ruang untuk bangunan perumahan dan status pemilikan lahan sebagian besar milik pribadi berasal dari warisan. Peran serta masyarakat dalam pemanfaatan fasilitas permukiman cukup tinggi, ditunjukkan dari keterkaitan erat antara lokasi perumahan dengan fasilitas jalan, pengelolaan limbah cair dan sampah, drainase, fasilitas umum berupa RTH.
\end{abstract}

Kata kunci: partisipasi masyarakat lokal, perencanaan dan pemanfaatan ruang, kawasan permukiman

\begin{abstract}
This article presents the research's result about (1) public knowledge of spatial planning and it's implementation; (2) the role of the community in implementing and controlling the use of space in the spatial planning; (3) the right of people in the utilization of space, and control the use of space. The research was carried out in Temanggung district used survey method for data collecting from 80 households are taken randomly. The data were processed using scoring techniques for quantifying qualitative data. Analysis technique was done qualitatively and quantitatively.This research shows that peoples in urban area have better socioeconomic condition than the peoples who live in urban fringe area, in term of average income rate. Howewer, both of them have little knowledge about Spatial Planing and it's implementation, due to lack of socialisation from the government. Therefore, their participation on implementing the spatial planning and controlling land utilisation also poor. Public right on land utilisation is showed by settlement and land ownership which mostly from legacy. Peoples participation on facilities utilisation is good enough, which is showed by their settlements that associated with roads, sewerage, garbage management, drainage channel, and green open space.
\end{abstract}

Keywords: local community participation, spatial and utilization planning, residential areas 


\section{PENDAHULUAN}

Permasalahan tata ruang menyangkut berbagai aspek, antara lain (Handiman, 2006): (a) kebijakan Pemerintah yang tidak sepenuhnya berorientasi kepada masyarakat, (b) para pelaku pembangunan tidak terbuka dalam menyelenggarakan proses penataan ruang (gap feeling); (c) rendahnya upaya-upaya pemerintah dalam memberikan informasi tentang akuntabilitas dari program penataan ruang; (d) partisipasi masyarakat sudah menjadi kepentingan bersama (common interest), namun pemahaman masyarakat masih terbatas; (e) tidak optimalnya kemitraan atau sinergi antara swasta dan masyarakat dalam penyelenggaraan penataan ruang; dan (f) persoalan perencanan partisipatif saat ini antara lain panjangnya proses pengambilan keputusan. Jarak antara penyampaian aspirasi hingga jadi keputusan relatif jauh.

Sebenarnya permasalahan tata ruang dalam kaitannya dengan peranserta masyarakat dan perhatian daya dukung lingkungan, sudah diatur secara hukum dalam penataan ruang dari tahapan perencanaan, pemanfaatan dan pengendalian ruang. Melalui UU Otonomi Daerah No. 21 tahun 2000, dikemukakan bahwa pemerintah pusat memberikan persentase kewenangan yang lebih besar untuk daerah dalam mengatur daerahnya sendiri secara mandiri. Namun demikian di dalam UU 32/2004 tentang Otonomi Daerah, telah terjadi penggeseran pemahaman dan pengertian dari banyak pihak, tentang usaha pemanfaatan sumber daya alam, terutama asset yang selama ini dianggap untuk kepentingan pemerintahan pusat dengan segala perijinan dan aturan yang menimbulkan perubahan kewenangan.

Perubahan sebagai tanggapan dari ketidakadilan selama ini, seperti perubahan dalam pengelolaan sumber daya alam yang tidak diikuti oleh aturan yang memadai, serta tidak diikuti oleh batasan yang jelas dalam menjaga keseimbangan fungsi regional atau nasional. Meskipun di dalam UU tersebut desa juga dinyatakan sebagai daerah otonom, namun tidak memiliki kewenangan yang jelas. Dengan kata lain, sebagian besar kebijakan publik, paling rendah masih diputuskan di tingkat kabupaten. Padahal, mungkin masalah yang diputuskan sesunggguhnya cukup diselesaikan di tingkat lokal (desa). Panjangnya rentang pengambilan keputusan tersebut merupakan potensi terjadinya deviasi, yang pada gilirannya menyebabkan banyak kebijakan publik yang tidak sesuai dengan aspirasi masyarakat.

Dalam Undang-Undang Nomor 26 Tahun 2007 tentang Penataan Ruang disebutkan, bahwa penyelenggaraan penataan ruang bertujuan untuk mewujudkan ruang yang aman, nyaman, produktif, berkelanjutan. Penataan ruang diharapkan mampu mengharmonisasi lingkungan alami dan buatan, memadukan penggunaan sumberdaya, serta melindungi fungsi ruang demi mencegah pengaruh negatif, yang mungkin diterima lingkungan sebagai akibat dari pemanfaatan ruang. Berkenaan dengan UU No. 32 tahun 2004 isi UU Nomor 26 Tahun 2007 tersebut, serta tentang Pemerintahan Daerah, maka kewenangan pemerintah kabupaten dalam penyelenggaraan penataan ruang mencakup: (1) pengaturan, pembinaan, dan pengawasan terhadap penataan ruang wilayah kabupaten dan atau kota; (2) pelaksanaan penataan ruang wilayah; (3) pelaksanaan penataan ruang kawasan strategis; (4) kerjasama penataan ruang antar kabupaten/kota, dan (5) memberi fasilitas kerjasama penataan ruang antarkabupaten atau kota.

Dalam Undang-Undang Nomor 26 Tahun 2007, Pasal 25 ayat (2) butir d, dikemukakan bahwa penyusunan rencana tata ruang wilayah (RTRW) kabupaten harus memperhatikan daya dukung dan daya tampung lingkungan hidup, dan Pasal 65 ayat (3), tentang peran serta masyarakat dalam penataan ruang, sebagaimana dimaksud pada ayat (1) dilakukan antara lain melalui partisipasi dalam penyusunan RTRW, pemanfaatan ruang, dan pengendalian pemanfaatan ruang. Berdasarkan pada Undang-undang Perlindungan dan Pengelolaan Lingkungan Hidup No. 32 Tahun 2009 pada Bab XI, Pasal 70, tentang Peranserta Masyarakat, dinyatakan bahwa masyarakat memiliki hak dan kesempatan yang sama dan seluas-luasnya untuk berperanserta aktif untuk perlindungan dan pengelolaan lingkungan hidup.

Peranserta seseorang dalam suatu objek kegiatan tidak lepas dari tiga aspek (Ritohardoyo, 2010): (1) pengetahuan tentang objek kegiatan, (2) persepsi mengenai 'biaya' objek kegiatan, dan (3) persepsi tentang manfaat dan risiko kegiatan. Variasi ketiga aspek tersebut tidak lepas dari pengaruh ciri sosio-ekonomik seseorang, maupun lingkungan biofisik dan lingkungan budaya (Gambar 1.). Pengetahuan seseorang tentang penataan ruang merupakan salah satu faktor penentu pilihan, yang mendorong individu untuk berperanserta. Pembuatan keputusan memerlukan suatu perhitungan tentang hasil, dan manfaat yang akan diperoleh, serta perhitungan kemungkinan risiko kegagalan yang akan dihadapi pada masa mendatang. Demikian juga persepsi tentang biaya, manfaat, dan risiko objek kegiatan akan mempengaruhi seseorang untuk mengambil keputusan berperanserta atau tidak berperanserta dalam objek kegiatan tersebut. 


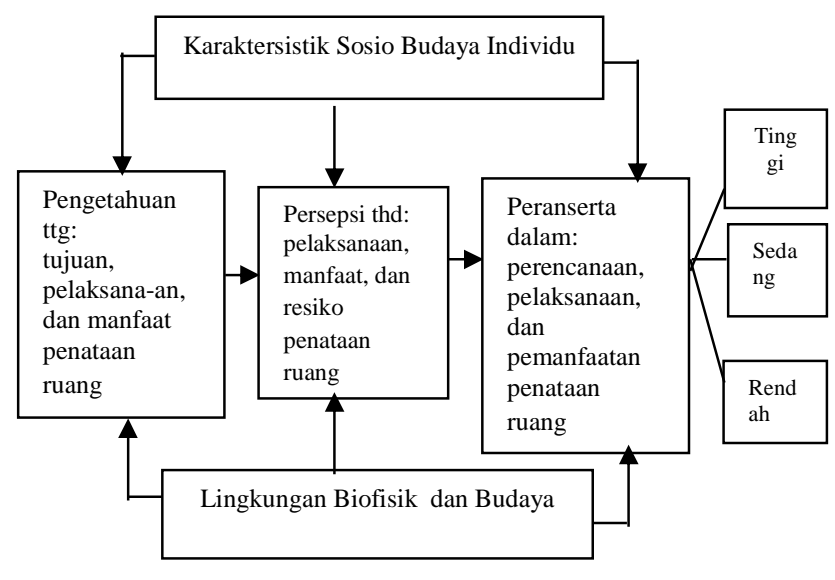

Gambar 1. Hubungan Peranserta dengan FaktorFaktor Pengaruh

Beberapa asumsi dapat diajukan, pertama jika seseorang memahami tujuan dan manfaat penataan ruang, dan memiliki kemampuan penilaian yang cukup tentang biaya dan waktu yang harus disediakan dalam ikut serta pada penataan ruang; maka yang bersangkutan akan memperhitungkan risiko dan untung ruginya dalam berperanserta. Seseorang yang memahami manfaat dan memiliki kepentingan, serta memahami pengorbanan (biaya, waktu, dan tenaga kerja) yang harus dikeluarkan, cenderung berpatisipasi tinggi, jika manfaat yang akan diperoleh lebih besar daripada pengorbanan.

Kedua, walaupun seseorang memahami tujuan dan manfaat penataan ruang, tetapi tidak melihat kemungkinan manfaat yang seimbang dengan pengorbanannya untuk memanfaatkan ruang, maka cenderung berperanserta rendah dalam penataan ruang. Demikian juga seseorang cenderung akan berperanserta rendah dalam penataan ruang jika: (1) tidak memiliki kepentingan mendesak untuk memanfaatkan ruang, (2) mengetahui bahwa apabila tidak berperan-serta tidak ada sanksinya, dan (3) memiliki persepsi bahwa pengorbanan yang harus dikeluarkan relatif besar tidak sesuai dengan manfaatnya.

Penataan ruang bertujuan untuk mewujudkan ruang yang aman, nyaman, produktif, berkelanjutan. Penataan ruang diharapkan mampu mengharmonisasi lingkungan alami dan buatan, memadukan penggunaan sumberdaya, serta melindungi fungsi ruang demi mencegah pengaruh negatif, yang mungkin terjadi dan diterima lingkungan sebagai akibat dari pemanfaatan ruang. Dalam kaitannya dengan tujuan perencanaan lingkungan adalah untuk mendapatkan gambaran lingkungan seperti apa yang diinginkan oleh masyarakat setempat (penghuni). Untuk mendapatkan ini, tentunya informasi tentang partisipasi masyarakat mutlak diperlukan. Dalam kenyataannya, pada tingkat ini jumlah masyarakat yang terlibat sangat kecil, padahal di tingkat inilah kemungkinan penentuan kebijakan yang demokratis dapat diwujudkan. Oleh karena itu dilakukan kajian tentang peranan masyarakat lokal dalam perencanaan ruang kawasan permukiman menngambil kasus Kabupaten Temanggung.
Kabupaten Temanggung telah memiliki Rencana Tata Ruang Wilayah (RTRW) Tahun 20112031 yang dikuatkan dengan Peraturan Daerah Kabupaten Temanggung No. 1 Tahun 2012 tentang Rencana Tata Ruang Wilayah (Sekda. Kab. Temanggung, 2012). Dalam kasus ini, mengacu pada UU Nomor 1 Tahun 2011 tentang Perumahan dan Kawasan Permukiman (Lembaran Negara RI Tahun 2011 No. 7, dan No. 5188), dipilih Kecamatan Temanggung, sebagai lokasi kajian perencanaan ruang kawasan perumahan dan permukiman. Alasannya, karena memiliki posisi sebagai pusat Ibukota Kabupaten Temanggung, dan pusat segala kegiatan dengan berbagai fungsi penting bagi daerah, di samping mampu menyumbangkan SPPT PBB terbesar di antara daerah-daerah kecamatan lain di Kabupaten Temanggung.

Secara deskriptif komparatif implikasi RTRW 2011-2031 pada perencanaan lingkungan perumahan dan permukiman Kecamatan Temanggung, dengan mengacu pada Standar Nasional Indonesia (SNI 03-1733-2004, 2004), dapat dihasilkan rumusan yang secara potensial dapat menunjang pembentukan model peran masyarakat dalam perencanaan ruang kota. Jika dicermati makna tujuan perencanaan lingkungan menyangkut harapan mendapatkan 'gambaran' lingkungan seperti apa yang diinginkan oleh masyarakat setempat (sebagai penghuni). Untuk mendapatkan ini, partisipasi masyarakat mutlak diperlukan. Peranserta masyarakat dalam perencanaan ruang wilayah secara formal, baru tertuang pada UU No. 24 Tahun 1992 tentang Penataan Ruang, yang selanjutnya diikuti oleh Peraturan Pemerintah, pada tanggal 3 Desember 1996, yaitu PP No.69 Tahun 1996 tentang Pelaksanaan Hak dan Kewajiban, serta Bentuk dan Tata Cara Peranserta Masyarakat dalam Penataan Ruang.

Dalam RTRW Kabupaten Temanggung Tahun 2011-2031, disebutkan bahwa untuk kegiatan penataan ruang wilayah, masyarakat setempat berhak: (1) berperanserta dalam perencanaan, pemanfaatan dan pengendalian pemanfaatan ruang; (2) mengetahui secara terbuka rencana tata ruang wilayah Kota Temanggung; (3) menikmati pemanfaatan ruang atau pertambahan nilai ruang akibat dari penataan ruang; (4) memperoleh penggantian yang layak atas kondisi yang dialaminya akibat pelaksanaan kegiatan pembangunan yang sesuai dengan rencana tata ruang; (5) mengajukan keberatan pada masa atau periode tertentu yang ditetapkan; dan (6) mendapat perlindungan dari kegiatan-kegiatan yang merugikan.

Berdasarkan pada masalah tersebut penelitian ini bertujuan untuk mengkaji (1) pengetahuan masyarakat tentang RTRW dan pelaksanaan RTRW; (2) peranserta masyarakat dalam melaksanakan kewajiban pada RTRW dan pengendalian pemanfaatan ruang dalam proses pelaksanaan RTRW; (3) hak masyarakat dalam 
pemanfaatan ruang, dan pengendalian pemanfaatan ruang.

\section{DATA DAN METODE PENELITIAN}

Penelitian dilaksanakan di Kecamatan Temanggung, terutama di Bagian Wilayah Perkotaan yang selanjutnya disingkat BWP dan Bagian Wilayah Perdesaan Pingiran Kota (BWPPK). Berdasar pada pembagian daerah tersebut, penelitian ini secara khusus mengambil lokasi kawasan BWP Kecamatan
Temanggung, yang secara keruangan dilaksanakan pada blok utama di pusat kota yakni Kalurahan Temanggung I, dan blok kedua di BWPPK yakni Kelurahan Kowangan (Gambar 1. dan Tabel 1.). Pertimbangannya, untuk memperoleh kebutuhan data secara komparatif keruangan dapat terpenuhi, dengan mengukur aspek sosial ekonomi dan respon masyarakat terhadap pelaksanaan RTRW.

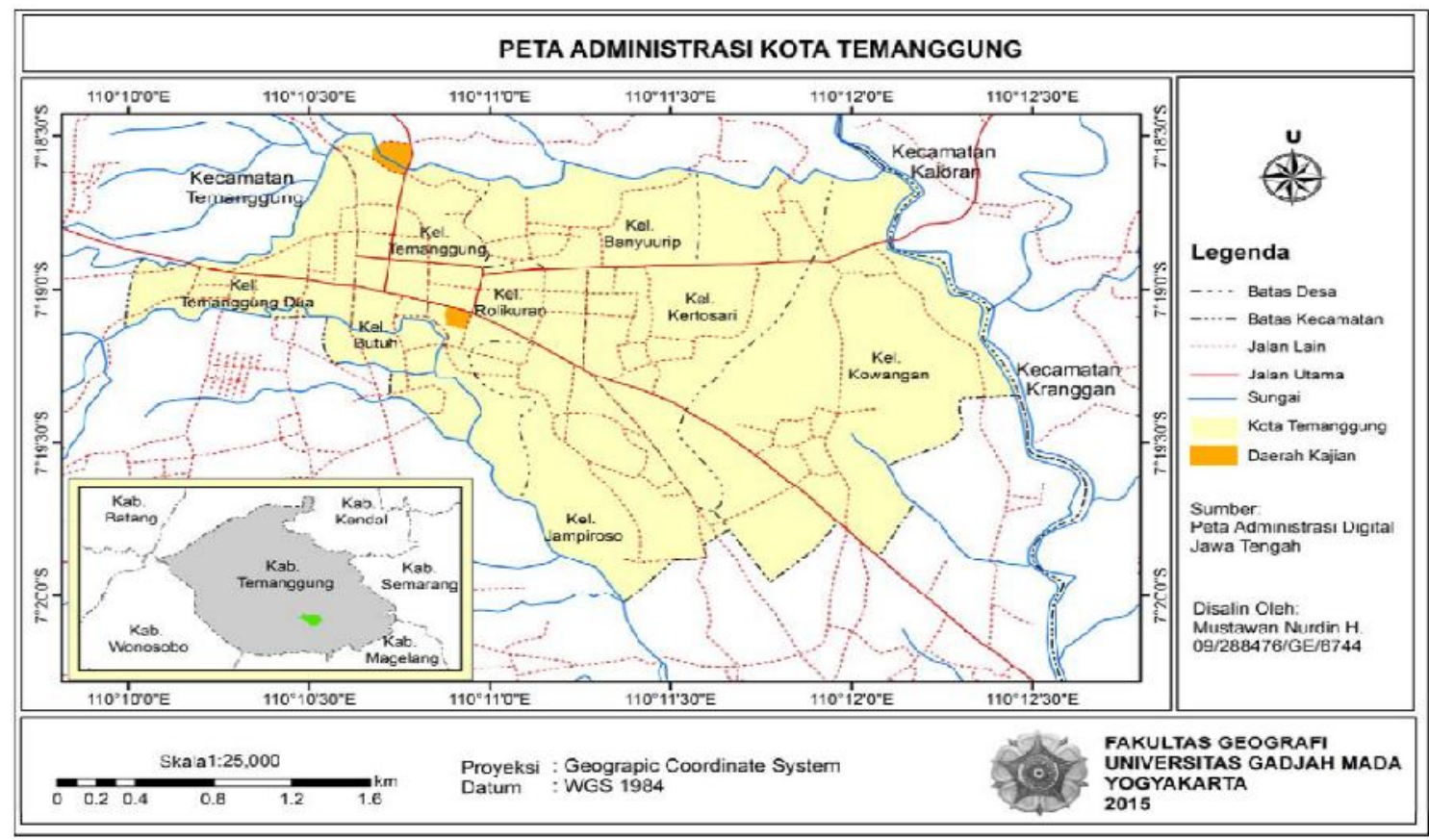

Gambar 1. Peta Administrasi Kota Temanggung

Tabel 1. Luas Lahan menurut Blok Areal di Sub BWP Temanggung

\begin{tabular}{clrrlr}
\hline No & Nama Blok & $\begin{array}{c}\text { Luas } \\
\text { (Ha) }\end{array}$ & No & $\begin{array}{c}\text { Nama } \\
\text { Blok }\end{array}$ & $\begin{array}{r}\text { Luas } \\
\text { (Ha) }\end{array}$ \\
\hline 1 & Temanggung & 41 & 13 & Jurang & 108 \\
& I & & & Tlogorejo & 230 \\
2 & Temanggung & 76 & 14 & & \\
& II & & & & \\
3 & Jampiroso & 66 & 15 & Manding & 163 \\
4 & Jampirejo & 86 & 16 & Kebonsari & 88 \\
5 & Butuh & 32 & 17 & Sidorejo & 160 \\
6 & Banyuurip & 56 & 18 & Walitelon & 181 \\
& & & & Utara & \\
7 & Kertosari & 147 & 19 & Walitelon & 179 \\
& & & & Selatan & \\
8 & Kowangan & 196 & 20 & Joho & 94 \\
9 & Madureso & 238 & 21 & Gilingsari & 128 \\
10 & Purworejo & 107 & 22 & Guntur & 67 \\
11 & Giyanti & 93 & 23 & Lungge & 153 \\
12 & Mungseng & 104 & 24 & Mudal & 287 \\
& Luas Total & & & & 3080 \\
\hline
\end{tabular}

Sumber: Bappeda Kab. Temanggung, 2015.
Dua jenis data yang diperlukan dalam penelitian ini adalah data primer dan data sekunder. Data primer maupun data sekunder dijabarkan dari beberapa variabel utama. Jenis data yang digunakan secara rinci, beserta sumbernya tersebut dapat ditunjukkan pada Tabel 2. berikut. Responden di dua kelurahan sebesar $1.611 \mathrm{KK}$, dengan jumlah sampel yang diambil sebanyak 5 persen dari seluruh jumlah populasi, adalah sebanyak $80 \mathrm{KK}$ dianggap representatif. Asumsinya setiap reponden dalam populasi mempunyai kesempatan yang sama untuk terpilih sebagai sampel. Penentuan jumlah sampel di setiap kelurahan dilakukan secara acak proporsional sederhana sebanyak 44 KK untuk Kelurahan Temanggung I, dan 36 KK di Kelurahan Kowangan. 
Tabel 2. Jenis Data dan Sumber Data di Daerah Penelitian

\begin{tabular}{ll}
\hline No. & \multicolumn{1}{c}{ Jenis Data } \\
\hline 1. & $\begin{array}{l}\text { DATA PRIMER } \\
\text { responden (jenis kelamin, umur, jumlah } \\
\text { anggota keluarga, pendidikan, pekerjaan, } \\
\text { pemilikan pekarangan, pertanian, dan } \\
\text { pendapatan) }\end{array}$ \\
2. & $\begin{array}{l}\text { Pengetahuan tentang undang-undang tata } \\
\text { ruang, RTRW, sumber informasi, tujuan, } \\
\text { manfaat, pelaksanaan, dan tentang } \\
\text { keuntungan dan kerugian. }\end{array}$ \\
3. Persepsi terhadap undang-undang tata ruang, \\
RTRW, sumber informasi, tujuan, manfaat, \\
pelaksanaan, dan tentang keuntungan dan \\
kerugian.
\end{tabular}

Data hasil pengukuran maupun data yang telah diperoleh dari sumber lain, dianalisis menggunakan dua cara, baik analisis kuantitatif maupun analisis kualitatif.

(1) Analisis kualitatif dilakukan dengan cara deskriptif untuk karakteristik responden, yakni dengan cara menyusun uraian atas dasar nilai relatif dari setiap faktor, yang mempengaruhi dalam pengambilan keputusan partisipasi dalam pelaksanaan RTRW. Analisis kualitatif lainnya mencitra kawasan permukiman atas dasar RTRW dan RDTR. Oleh karena itu analisis mencakup dua hal:

(a) Karakteristik sosial ekonomi responden baik meliputi jenis kelamin, umur, pendidikan, pekerjaan, pemilikan asset, serta pendapatan.

(b) Penilaian responden terhadap variabelvariabel yang terkait dengan pelaksanaan RTRW dan RDTR, baik pelaksanaan kewajiban dan pemanfaatan hak perlindungan.
(2) Analisis kuantitatif, dilakukan untuk menjawab beberapa pertanyaan penelitian rinci, terutama analisis komparatif ataupun korelasional. Keberlakuan jawaban pertanyaan penelitian rinci diuji menggunakan analisis tabulasi silang. Penyusunan rekomendasi untuk pelaksanaan RTRW didasarkan pada hasil analisis aspek pengetahuan, persepsi, dan partisipasi masyarakat dalam kaitannya dengan undangundang tata ruang dan RTRW.

\section{HASIL PENELITIAN DAN PEMBAHASAN}

\section{A. Karakteristik Sosial Ekonomi Penghuni Kawasan Permukiman}

Kawasan permukiman adalah areal di luar kawasan lindung, yang diperuntukan sebagai lingkungan tempat hunian penduduk, dan tempat kegiatan untuk mendukung kehidupan dan penghidupan. Peruntukan lahan permukiman, Kabupaten Temanggung seluas 14.698 hektar, mencakup kawasan permukiman perkotaan dan perdesaan. Namun demikian luas kawasan permukiman perkotaan terutama Kecamatan Temanggung hanya sebesar 46,95 persen atau $69 \mathrm{~km}^{2}$ (BPS. Kab. Temanggung, 2013).Daerah perkotaan seluas itu terbagi ke dalam delapan kelurahan, dengan luas bervariasi antara $3,7 \mathrm{~km}^{2}$ hingga $21,5 \mathrm{~km}^{2}$. Jumlah total penghuni oleh 31.988 jiwa dengan variasi antara 3.237 jiwa (Kelurahan Butuh) hingga 5.425 jiwa (Kelurahan Kertosari). Kepadatan penduduk terendah sebesar $185 \mathrm{jiwa} / \mathrm{km}^{2}$ (Kelurahan Kowangan), tertinggi 875 jiwa $/ \mathrm{km}^{2}$ di Kelurahan Butuh, sedangkan Kepadatan penduduk di Kota Temanggung 464 jiwa/ $\mathrm{km}^{2}$ (Tabel 3.).

Kepadatan penduduk tertinggi di Kelurahan Butuh karena lokasinya berbatasan dengan pusat kota dan luas daerahnya paling sempit $(3,7 \mathrm{Km} 2)$. Hal ini berbeda dari jumlah penduduk Kelurahan Kowangan mempunyai jumlah penduduk sedikit, namun daerahnya terluas sehingga meskipun letaknya berada di pinggiran kota menyebabkan kepadatan penduduk Kelurahan Kowangan paling rendah 185 (jw/Km2). Jumlah dan kepadatan penduduk, serta dinamikanya merupakan salah satu aspek penting dalam menentukan kuantitas, jenis, dan kualitas permukiman. Jumlah penduduk berbanding lurus dengan kebutuhan ruang, terutama untuk permukiman dan fasilitas umum. Akibatnya Kota Temanggung semakin padat dan berkembang ke pinggiran kota, dan berpengaruh terhadap perkembangan prasarana dan sarana sosial ekonomi. 
Tabel 3. Jumlah Penduduk Kota Temanggung

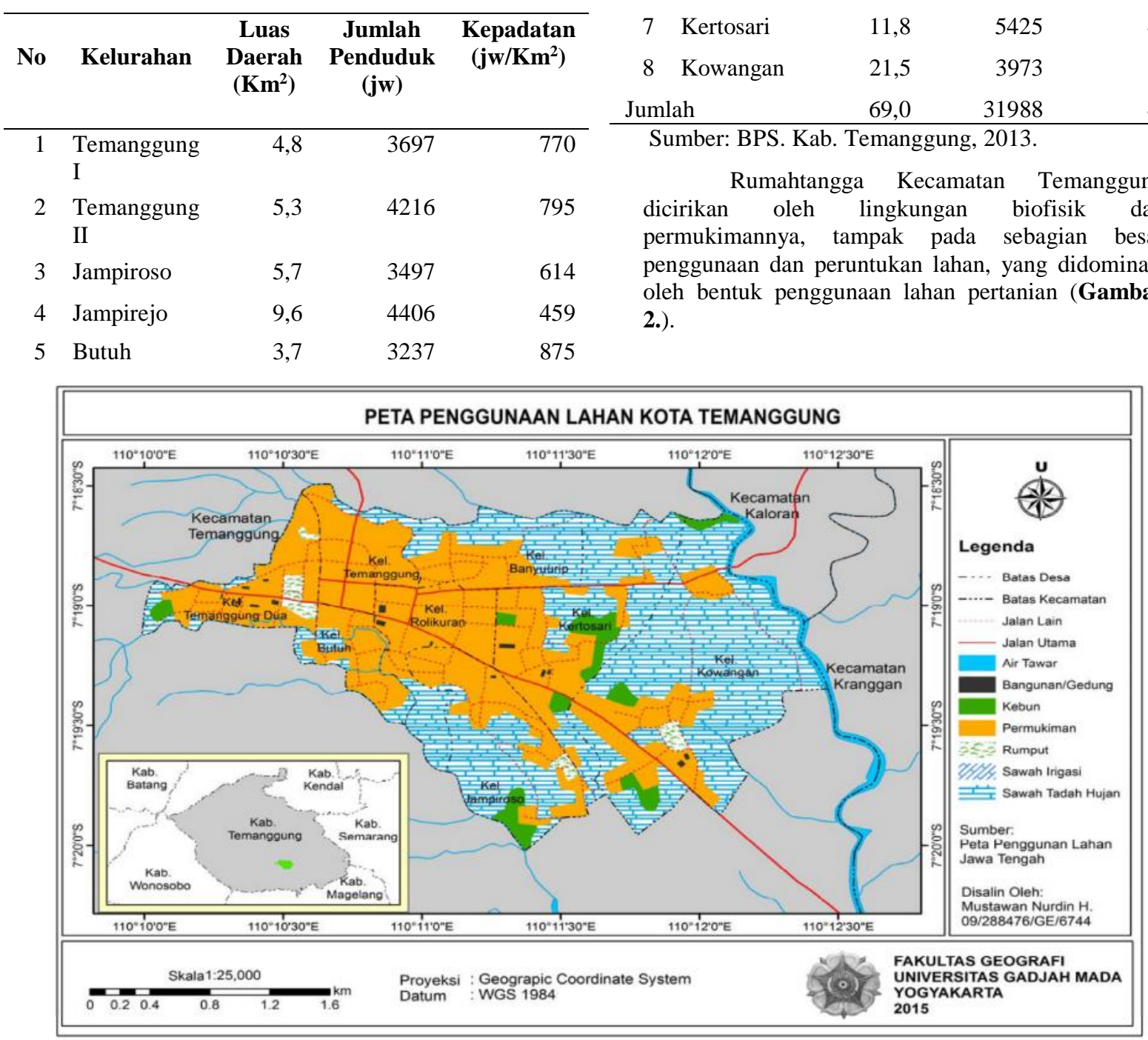

Gambar 2. Peta Penggunaan Lahan Kota Temanggung
Sebagian besar masyarakat perkotaan Temanggung (76\%) bekerja di sektor non pertanian, sedangkan yang bekerja di sektor pertanian tinggal sebesar (24\%). Di antara anggota masyarakat menuturkan, bahwa mata pencaharian sebagai petani bukan menjadi satu-satunya matapencaharian utama. Mereka yang bekerja sebagai petani juga bekerja sebagai pedagang, atau pegawai negeri. Mata pencaharian rumahtangga banyak mengalami diversifikasi sejalan dengan perkembangan perkotaan Temanggung, yang berpengaruh pada kemampuan menjangkau kebutuhan hidup.

Peran masyarakat dan daerah kecamatan ini tampakpada besarnya sumbangan tertinggi pada PDRB Kabupaten Temanggung (12,96\% atau Rp. 896.244.840,-). Kecamatan ini sebagai pusat kota pemerintahan dan ekonomi kabupaten, menempati posisi peranan tertinggi di antara 20 kecamatan yang ada. Peranan terbesar Kecamatan Temanggung terdukung oleh sektor jasa, yang berperan tertinggi $(30,0 \%)$, sektor perdagangan, hotel dan restoran

(20,0\%), dan peran sektor pertanian sebesar 14,0 persen. Laju pertumbuhan PDRB kecamatan bervariasi baik menurut harga yang berlaku maupun harga konstan. Pertumbuhan ekonomi menurut harga berlaku sebesar $14,15 \%$, dan menurut harga konstan sebesar 7,47\%. Kemampuan daerah dalam menciptakan nilai tambah per satu orang penduduk dalam jangka waktu satu tahun, ditunjukkan dari kenaikan PDRB perkapita sebagai salah satu indikator kesejahteraan, yakni sebesar 13,16 persen, selama tahun 2012-2013.

Karakteristik kawasan perkotaan yang tercermin pada dominasi pekerjaan penduduk di sektor non pertanian dan kegiatan sosial budaya, tampak pada sarana dan prasarana kegiatan ekonomi berupa pasar, perkantoran negeri dan swasta, 
berada di kota bagian selatan, sedangkan pusat pelayanan pemerintahan terdapat di kota bagian utara dan barat. Daerah perkotaan sebagai pusat ekonomi membutuhkan banyak sumberdaya manusia sebagai penggeraknya. D ata B PS Kabupaten Temanggung (2015) menunjukkan bahwa p enduduk di pusat Kota Temanggung (Kelurahan Temanggung) banyak bergantung pada sektor perdagangan, swasta, dan jasa. Selain itu juga bergantung pada sektor industri pengolahan dan pengangkutan, sebagian kecil penduduk menjadi pegawai negeri. Pekerjaan sebagai petani masih digeluti oleh sebagian penduduk yang bermukim didaerah perkotaan pinggiran (Kelurahan Kowangan), yang masih terdapat lahan untuk bertani. Penduduk di pinggiran kota banyak yang bekerja di sektor informal sebagai sopir, buruh, dan karyawan toko, serta berwiraswasta di samping sebagai petani.

Aspek penting terkait dengan sosial ekonomi masyarakat perkotaan ini adalah pendapatan rumahtangga, yang bermanfaat untuk memenuhi kebutuhan hidup mereka. Peningkatan pendapatan dapat sebagai penentu status sosial masyarakat, dimana keadaan pendapatan masyarakat secara potensial dapat menggambarkan status kualitas tempat tinggal yang semakin baik. Asumsinya, jika kebutuhan primer terpenuhi maka kelebihan pendapatan diarahkan untuk meningkatkan kesejahteraan dan statussosial, salah satunya adalah peningkatan kualitas bangunan rumah tempat tinggal.

Hasil penelitian mengenai penghasilan rumahtangga, di kawasan perkotaan Kabupaten Temanggung bervariasi sejalan dengan variasi jenis pekerjaan. Kelompok masyarakat berpendapatan rendah ( $<$ Rp 1.000.000) lebih banyak (Tabel 4.). di kawasan permukiman pinggiran kota $(46,7 \%)$ daripada di kawasan permukiman pusat kota $(6,5 \%)$. Kesamaan proporsi pendapatan antara masyarakat di pusat kota dengan masyarakat di pinggiran kota $(>50,00 \%)$, terjadi pada kelompok masyarakat berpendapatan kategori cukup (Rp 1.000.001 - Rp. 3.000.000,-). Ditinjau dari besarnya rerata pendapatan terdapat perbedaan yang cukup mencolok, yakni pendapatan kelompok masyarakat per bulan di pusatkotalebih tinggi (Rp. 2.998.500,) dari pada pendapatan kelompok masyarakat per bulan di pinggirankota (Rp.1.299.500,-). Kenyataan ini menunjukkan bahwa semakin kearah luar kota rerata pendapatan masyarakat semakin rendah, di bawah upah minimum kota (UMK), yang besarnya Rp. 1.313.000,-/bulan (Anonimus, 2016). Maknanya, peran kota sebagai pusat kegiatan ekonomi non pertanian lebih memiliki kemampuan memberikan kesempatan kerja dan kesejahteraan penghuninya lebih baik, daripada di pinggiran kota. Perbedaan kondisi sosial ekonomi masyarakat di pusat kota dengan di pinggiran kota, berimplikasi pada perbedaan potensi pemanfaatan ruang untuk kawasan permukiman.
Tabel 4. Komposisi Rumah Tangga Berdasar Pendapatan

\begin{tabular}{lccccc}
\hline No & $\begin{array}{c}\text { Lokasi } \\
\text { Permukiman } \\
\text { Komponen }\end{array}$ & \multicolumn{3}{c}{ Kawasan Permukiman } \\
\cline { 2 - 6 } & $\begin{array}{c}\text { Pendapatan } \\
\text { (Rp. /bulan) }\end{array}$ & $\begin{array}{c}\text { Juml } \\
\text { ah }\end{array}$ & Persen & Jumlah & Persen \\
\hline 1. & $<1.000 .000$ & 3 & 6,5 & 17 & 46,7 \\
2. & $1.000 .001-$ & 24 & 54,8 & 19 & 53,3 \\
& 3.000 .000 & & & & \\
3. & $3.000 .001-$ & 10 & 22,6 & 0 & 0,0 \\
& 5.000 .000 & & & & \\
$4 . \quad$ & $>5.000 .000$ & 7 & 16,1 & 0 & 0,0 \\
Total & 44 & 100,0 & 36 & 100,0 \\
$\begin{array}{l}\text { Rerata Pendapatan } \\
\text { (Rp/bulan) }\end{array}$ & 2.998 .500 & 1.299 .500 \\
\hline
\end{tabular}

Sumber: Analisis Data Primer, 2016

Perkembangan wilayah perkotaan

Temanggung sangat bergantung pada faktor ekonomi, yang berperanan sebagai faktor penentu dan pemicu untuk terjadinya suatu pengembangan wilayah. Ekonomi bergerak secara menyeluruh dan memiliki pengaruh sangat besar pada setiap tipe wilayah. Ketidaksiapan suatu wilayah pada pengaruh ekonomi, akan berpengaruh langsung pada tingkat kesejahteraan masyarakat di wilayah tersebut, dan menuntut terjadinya suatu perkembangan agar untuk mengimbangi dinamika ekonomi yang terus maju. Pengaruh tersebut menyebabkan terjadinya dinamika spasial, sosial, dan ekonomi antardaerah kecamatan hingga perdesaan, bahkan antarrumahtangga.

Komposisi ruang untuk kawasan permukiman di kecamatan Temanggung cukup tinggi. Luas lahan pertanian sawah sebesar 42,01 persen, lebih sempit dari pada luas lahan non pertanian yang didominasi lahan untuk kawasan permukiman $(57,99 \%)$. Pemanfaatan lahan untuk permukiman, lebih banyak untuk tempat tinggal. Ditinjau dari aspek sebarannya lebih bersifat mengelompok, atau memiliki pola mengelompok. Keberadaannya dekat dengan lahan pertanian, sebagai perwujudan penataan ruang perdesaan alami, sehingga mempermudah masyarakat dalam mencapai tempat bekerja. Hal yang mencolok dari pola sebaran permukiman adalah mengelompok memusat, dimana pusat kota berada di pusat Kecamatan Temanggung dalam kelompok besar, sedangkan yang lain merupakan permukiman dalam kelompok kecil menyebar di daerah sekitarnya.

\section{B. Pengetahuan Masyarakat tentang Perencanaan Ruang Kawasan Permukiman}

Pengetahuan dalam penelitian ini diartikan sebagai pemahaman hasil pembelajaran, dan pengalaman seseorang dan atau sekelompok orang, yang terakumulasi sehingga dapat diaplikasikan ke dalam pemecahan masalah tertentu. Dalam kasus pengetahuan baik seseorang maupun sekelompok penghuni permukiman, menyangkut pemahaman 
tentang norma dan aturan, keberadaan, bentuk, ukuran, serta apa yang harus diperlakukan pada bangunan rumah tempat tinggal, beserta fasilitas dan lingkungannya. Ukuran pengetahuan dan pemahaman ditunjukkan dalam kaitannya dengan pendidikan sebagai salah satu sumber pengetahuan.

Akses terhadap pendidikan bagi masyarakat Kecamatan Temanggung, terutama di pusat kota dan pinggiran kota ternyata bervariasi, sehingga memungkinkan terjadinya variasi pengetahuan umum atau khusus tentang objek pembangunan. Pendidikan berperanan sebagai pembentuk polapikir pada masyarakat dalam kehidupannya, termasuk dalam hal tentang kawasan permukiman. Masyarakat yang berpendidikan tentunya akan lebih sadar tentang pentingnya permukiman yang berkualitas. Kepala keluarga yang pada umumnya bertanggungjawab terhadap urusan bangunan rumah tempat tinggal dan lingkungannya, maka dalam pengukuran pengetahuan mereka, pertama diukur tingkat pendidikannya, kedua diukur dari pengalaman mereka terkait dengan objeknya.

Hasil penelitian (Tabel 5.) menunjukkan bahwa jumlah kelompok kepala keluarga yang berpendidikan SLTA di pusat kota, lebih banyak $(61,3 \%)$ daripada jumlah kelompok kepala keluarga yang berpendidikan SLTA di kota pinggiran (36,5\%). Sebaliknya, kelompok kepalakeluarga berpendidikan SD dan SLTP $(29,1 \%)$ di pusat kota, lebih sedikit daripada kelompok kepala keluarga berpendidikan SD dan SLTP di pinggiran kota $(60,8 \%)$. Hal ini menunjukkan bahwa penduduk pusat kota memiliki pengetahuan umum lebih tinggi, daripada penduduk di pinggiran kota.

Tabel 5. Komposisi Rumahtangga Berdasar Pendidikan

\begin{tabular}{|c|c|c|c|c|}
\hline \multirow{2}{*}{$\begin{array}{c}\text { Lokasi } \\
\text { Permukima } \\
\text { n }\end{array}$} & \multicolumn{4}{|c|}{ Kawasan Permukiman } \\
\hline & Pusa & Kota & $\begin{array}{r}\text { Pinggi } \\
\text { Kot }\end{array}$ & \\
\hline Pendidikan & $\begin{array}{l}\text { Jum } \\
\text { lah }\end{array}$ & $\begin{array}{c}\text { Perse } \\
\text { n }\end{array}$ & Jumlah & $\begin{array}{c}\text { Perse } \\
\text { n }\end{array}$ \\
\hline 1. SD & 3 & 6,5 & 10 & 27,7 \\
\hline 2. SLTP & 10 & 22,6 & 12 & 33,1 \\
\hline 3. SLTA & 27 & 61,3 & 13 & 36,5 \\
\hline 4. D3 dan S1 & $\begin{array}{c}4 \\
44\end{array}$ & 9,7 & $\begin{array}{c}1 \\
36\end{array}$ & 2,7 \\
\hline Total & & 100,0 & & 100,0 \\
\hline
\end{tabular}

Sumber: Analisis Data Primer, 2016

Ditinjau dari pengetahuan penduduk yang lebih khusus, terutama tentang Undang Undang Tata Ruang (UUTR) dalam kaitannya dengan kawasan permukiman mereka, baik di pusat kota maupun di pinggiran kota, ternyata sebagian besar $(>70 \%)$ di antara mereka berpengetahuan rendah atau belum tahu (Tabel 6.). Ketidaktahuan tersebut disebabkan belum pernah memperoleh penerangan ataupun penyuluhan tentang pentingnya UUTR. Di antara mereka yang mengetahui UUTR mengaku memperoleh informasi dari media massa baik koran maupun televisi.

Tabel 6. Komposisi Rumahtangga Berdasar Pengetahuan tentang UUTR

\begin{tabular}{|c|c|c|c|c|c|}
\hline \multirow{3}{*}{$\begin{array}{l}\mathbf{N} \\
\mathbf{0}\end{array}$} & \multirow{3}{*}{$\begin{array}{c}\begin{array}{c}\text { Lokasi } \\
\text { Permukim } \\
\text { an }\end{array} \\
\begin{array}{c}\text { Pengetahu } \\
\text { an UUTR }\end{array} \\
\end{array}$} & \multicolumn{4}{|c|}{ Kawasan Permukiman } \\
\hline & & \multicolumn{2}{|c|}{ Pusat Kota } & \multicolumn{2}{|c|}{$\begin{array}{c}\text { Pinggiran } \\
\text { Kota }\end{array}$} \\
\hline & & $\begin{array}{l}\text { Jumla } \\
\text { h }\end{array}$ & $\begin{array}{c}\text { Perse } \\
\text { n }\end{array}$ & $\begin{array}{c}\text { Jumla } \\
\text { h }\end{array}$ & $\begin{array}{c}\text { Perse } \\
\text { n }\end{array}$ \\
\hline 1. & $\begin{array}{l}\text { Rendah } \\
(\text { skor }<12)\end{array}$ & 31 & 71,0 & 26 & 72,2 \\
\hline 2. & $\begin{array}{l}\text { Sedang } \\
\text { (skor } 12 \text { - } \\
<17 \text { ) }\end{array}$ & 10 & 22,6 & 9 & 25,0 \\
\hline 3. & $\begin{array}{l}\text { Tinggi } \\
(\text { skor } \geq 17)\end{array}$ & $\begin{array}{r}3 \\
44\end{array}$ & 6,5 & 36 & 2,8 \\
\hline & Total & & 100,0 & & 100,0 \\
\hline
\end{tabular}

Sumber: Analisis Data Primer, 2016

Kenyataan pengetahuan penduduk tentang UUTR dalam kaitannya dengan kawasan permukiman mereka, di kedua daerah yang relatif rendah adalah wajar. Hal ini di samping pengakuan masyarakat merasa belum pernah memperoleh penerangan ataupun penyuluhan tentang UUTR, juga didukung informasi dari penuturan informan di daerah penelitian, yang menyatakan memang belum pernah dilaksanakan penerangan ataupun penyuluhan tentang UUTR. Artinya peran Pemerintah Daerah Kabupaten Temanggung dalam usaha menyebarluaskan pengertian dan pentingnya UUTR kepada masyarakat, baik berwujud dokumen, dan peraturan daerah, belum disosialisasikan lewat berbagai penyuluhan.

Hasil penelusuran pengetahuan penduduk khususnya tentang Rencana Tata Ruang Wilayah (RTRW) dalam kaitannya dengan kawasan permukiman, baik di pusat kota maupun di pinggiran kota ternyata memiliki pola yang sama dengan pengetahuan tentang UUTR. Kesamaan terjadi pada sebagian besar $(>65 \%)$ di antara mereka memiliki pengetahuan rendah atau tidak memahami (Tabel 7.). Ketidak-pahaman mereka sebagai akibat belum pernah memperoleh penerangan atau penyuluhan langsung tentang pentingnya RTRW. Beberapa di antara mereka yang mengetahui tentang RTRW menyatakan memperoleh informasi dari media masa baik koran maupun televisi dan sebagian lagi memperoleh informasi dari internet web Kabupaten Temanggung. Mereka ini adalah kelompok kecil masyarakat yang berpendidikan SLTA, Diploma dan S1, yang berdomisili di pusat kota Temanggung.

Tabel 7. Komposisi Rumah Tangga Menurut Pengetahuan Tentang RTRW

N Lokasi Kawasan Permukiman




\begin{tabular}{|c|c|c|c|c|c|}
\hline \multirow[t]{2}{*}{ о } & \multirow{2}{*}{$\begin{array}{r}\text { Permukim } \\
\text { an }\end{array}$} & \multicolumn{2}{|c|}{ Pusat Kota } & \multicolumn{2}{|c|}{$\begin{array}{c}\text { Pinggiran } \\
\text { Kota }\end{array}$} \\
\hline & & $\begin{array}{l}\text { Jumla } \\
\text { h }\end{array}$ & $\begin{array}{c}\text { Perse } \\
\text { n }\end{array}$ & $\underset{\mathbf{h}}{\mathrm{Jumla}}$ & $\begin{array}{c}\text { Perse } \\
\text { n }\end{array}$ \\
\hline 1. & $\begin{array}{l}\text { Rendah } \\
(\text { skor }<12)\end{array}$ & 29 & 65,9 & 25 & 69,4 \\
\hline 2. & $\begin{array}{l}\text { Sedang } \\
\text { (skor } 12- \\
<17 \text { ) }\end{array}$ & 10 & 22,7 & 9 & 25,0 \\
\hline 3. & $\begin{array}{l}\text { Tinggi } \\
(\text { skor } \geq 17)\end{array}$ & 5 & 11,4 & 2 & 5,6 \\
\hline To & & 44 & 100,0 & 36 & 100,0 \\
\hline
\end{tabular}

Sumber: Analisis Data Primer, 2016

Kesamaan pengetahuan tentang RTRW pada kategori rendah antara masyarakat kawasan permukiman di pusat kota dengan di pinggiran kota adalah wajar, mengingat jarak lokasi kedua kawasan permukiman tersebut relatif dekat (jarak $\pm 5 \mathrm{~km}$ ). Di samping itu meski status administratif kelurahan termasuk perkotaan, namun sifat fisik pinggiran kota masih berupa permukiman perdesaan. Informasi dari penuturan beberapa Staf Bappeda Kabupaten Temanggung, hingga saat ini RTRW masih merupakan dokumen rencana, belum dilaksanakan penataan ruangnya. Dokumen RTRW tersebut masih dalam proses revisi beberapa hal untuk peneyempurnaan. Oleh karena itu adalah suatu kewajaran jika sebagian anggota masyarakat belum memahami tentang RTRW daerah tempat tinggalnya.

\section{PERSEPSI DAN PARTISIPASI MASYARAKAT TERHADAP PERENCANAAN RUANG KAWASAN PERMUKIMAN}

\section{1). Persepsi Masyarakat terhadap RTRW}

Masyarakat Kota Temanggung seperti dikemukakan di atas belum memiliki pemahaman yang cukup baik mengenai RTRW. Istilah RTRW sendiri memang belum begitu familiar bagi masyarakat awam, sehingga masih perlu adanya penjelasan lebih lanjut untuk mengetahui persepsi masyarakat terhadap kondisi RTRW, terutama di dua daerah kajian yakni di kawasan permukiman pusat kota dan pinggiran kota. Jika dibandingkan kedua kawasan tersebut dapat ditunjukkan pada Gambar 3. dan Gambar 4., mengenai Rencana Detil Tata Ruang (RDTR).

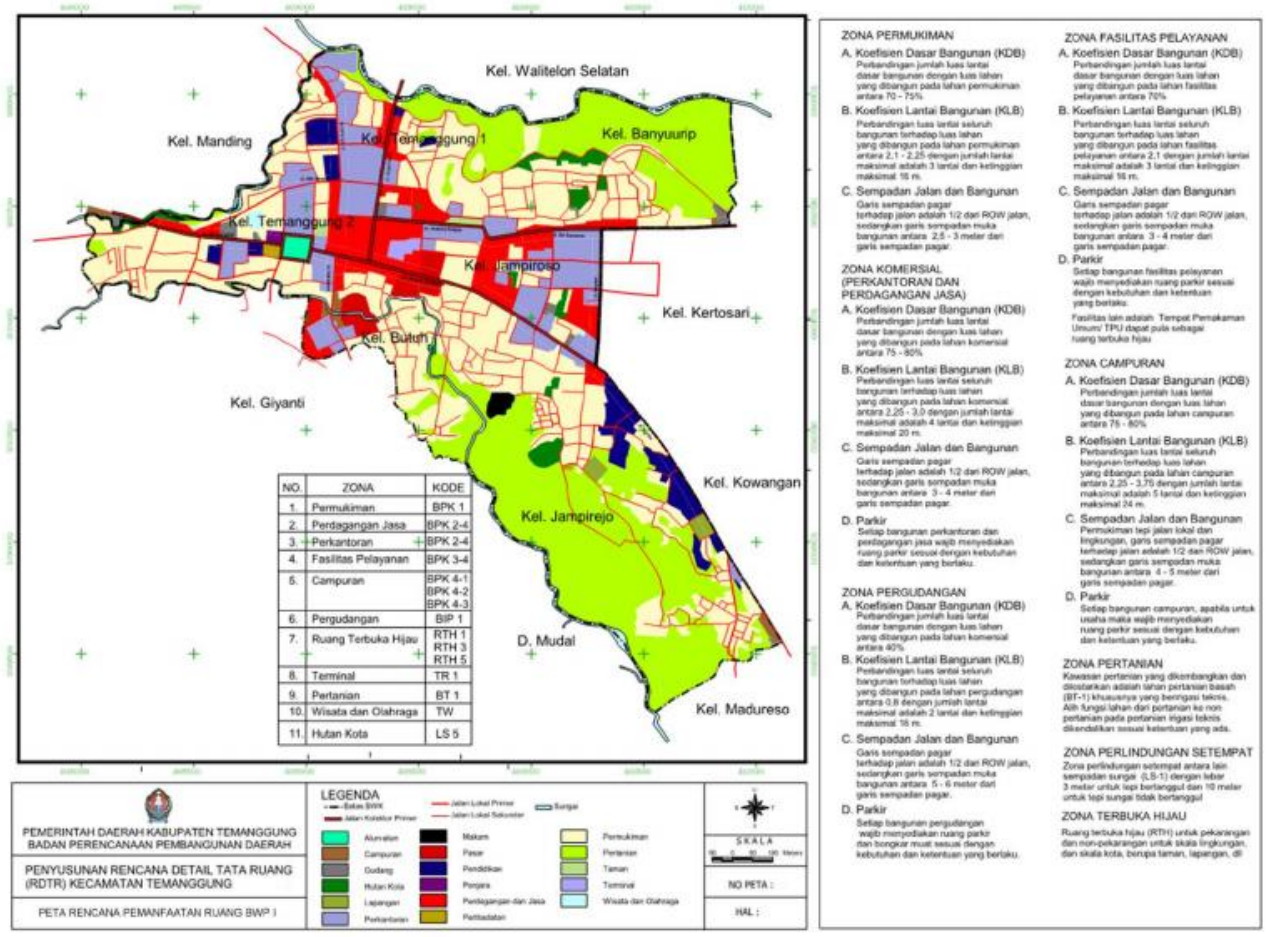

Gambar 3. Peta Rencana Pemanfaatan Ruang BWP I

Kondisi RDTR pusat kota yang terdapat di Kalurahan Temanggung memang yang paling luas adalah kawasan permukiman, disusul kawasan perkantoran, perdagangan dan jasa, industri, dan sarana pelayanan umum. 


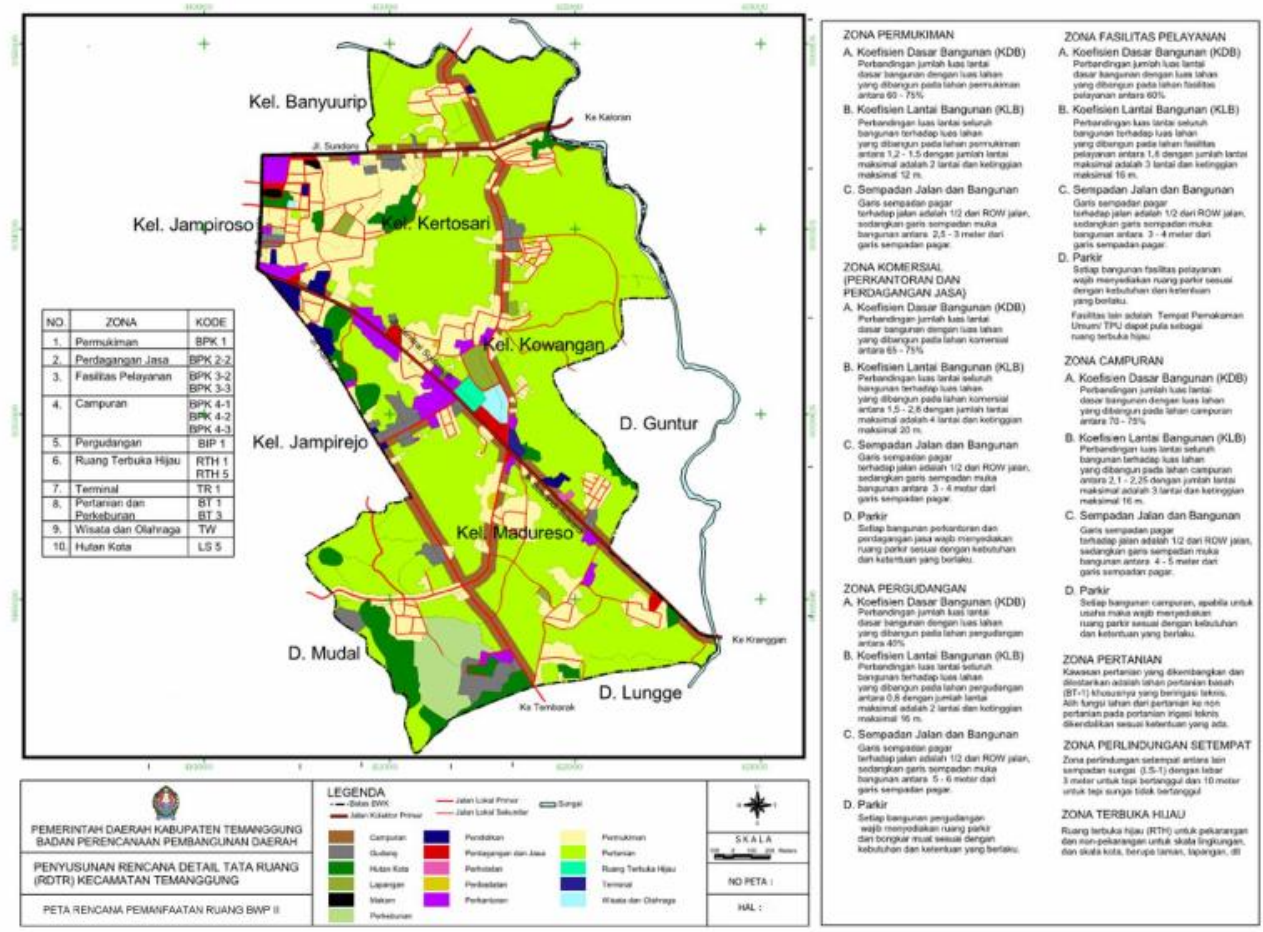

Gambar 4. Peta Rencana Pemanfaatan Ruang BWP II

Kawasan ruang terbuka hijau (RTH) baik RTH privat maupun RTH publik relatif sempit. Hal tersebit berbeda dengan kondisi RDTR yang terdapat di pinggiran kota, kawasan permukiman cukup luas, namun kawasan perkantoran, perdagangan dan jasa, industri, dan sarana pelayanan umum lebih sempit daripada di pusat kota. Demikian pula kawasan RTH proporsi RTH publik hanya sebagian kecil saja. Pandangan masyarakat terhadap proporsi tersebut memang dibenarkan oleh masyarakat. Hal tersebut karena masih banyaknya sawah, kebun, dan pekarangan rumah yang dimiliki oleh masyarakat, serta sebagian besar masyarakatnya bekerja sebagai petani.

Berkaitan dengan pandangan masyarakat terhadap distribusi peruntukan ruang tersebut, lebih lanjut ditelusuri persepsi mereka terhadap keberadaan RTRW dan RDTR di daerahnya. Persepsi mereka dapat dikategorikan menjadi 3 klas, persepsi rendah atau kurang baik, persepsi sedang atau cukup baik, dan persepsi tinggi berarti baik (Tabel 8.). Hasil analisis data persepsi masyarakat menunjukkan bahwa secara keruangan sebagian besar (hampir $60 \%$ ) persepsi masyarakat di pusat kota maupun pinggiran kota termasuk kategori rendah atau RTRW dianggap kurang baik bagi mereka. Hanya sebagian kecil saja yang menganggap RTRW dan RDTR tersebut baik.
Tabel 8. Komposisi Rumahtangga menurut Persepsi terhadap RTRW

\begin{tabular}{|c|c|c|c|c|c|}
\hline \multirow{3}{*}{$\begin{array}{r}\mathbf{N} \\
\mathbf{0}\end{array}$} & & \multicolumn{4}{|c|}{ Kawasan Permukiman } \\
\hline & $\begin{array}{r}\text { Permukim } \\
\text { an }\end{array}$ & \multicolumn{2}{|c|}{ Pusat Kota } & \multicolumn{2}{|c|}{$\begin{array}{c}\text { Pinggiran } \\
\text { Kota }\end{array}$} \\
\hline & $\begin{array}{l}\text { Persepsi } \\
\text { thd } \\
\text { RTRW }\end{array}$ & $\begin{array}{l}\text { Jumla } \\
\text { h }\end{array}$ & $\begin{array}{c}\text { Perse } \\
\text { n }\end{array}$ & $\begin{array}{c}\text { Jumla } \\
\mathbf{h}\end{array}$ & $\begin{array}{c}\text { Perse } \\
\text { n }\end{array}$ \\
\hline 1. & $\begin{array}{l}\text { Rendah } \\
(\text { skor }<16)\end{array}$ & 26 & 59,1 & 25 & 69,4 \\
\hline 2. & $\begin{array}{l}\text { Sedang } \\
\text { (skor } 16 \text { - } \\
<22 \text { ) }\end{array}$ & 10 & 22,7 & 8 & 22,2 \\
\hline 3. & $\begin{array}{l}\text { Tinggi } \\
\text { (skor } \geq 22)\end{array}$ & 8 & 18,2 & 3 & 8,3 \\
\hline Tot & & 44 & 100,0 & 36 & 100,0 \\
\hline
\end{tabular}

Sumber: Analisis Data Primer, 2016.

Alasan mereka yang mempersepsikan RTRW dan RDTR tidak baik, karena sampai saat penelitian dilakukan, mereka merasa tidak dan atau belum tahu apa keuntungan dan kerugian yang akan diperoleh, jika keberadaan rencana tersebut dilaksanakan. Misalnya bagi masyarakat yang berada di sekitar lokasi RTH publik berupa taman kota maupun rekreasi, stadion, dan jalur hijau, tidak terganggu dengan keberadaan ruang publik tersebut. Bahkan mereka mendapatkan manfaat dari adanya ruang publik karena dapat dimanfaatkan sebagai tempat rekreasi keluarga, tempat olah raga, bahkan 
sebagai tempat berjualan untuk menambah penghasilan.

Menurut masyarakat setempat yang kurang setuju terhadap keberadaan RTRW dan RDTR, karena ruang yang sudah dimanfaatkan baik di pusat kota maupun di pinggiran kota, sudah tertata dengan baik dan mereka merasa settled (krasan). Alasan ini cukup logis, mengingat sebagian besar dari mereka adalah penduduk asli, yang sudah adaptasi cukup lama terhadap lingkungan permukiman sekitarnya. Akibatnya mereka menganggap tidak perlu lagi adanya RTRW dan RDTR, karena mereka sudah puas dengan apa yang tersedia di lingkungannya.

Terkait dengan persepsi mereka terhadap salah satu komponen lingkungan permukiman yakni RTH di pusat kota, di antara mereka menyetujui jika pemerintah mau menambahkan lahan untuk RTH publik. Alasannya, ruang publik dapat digunakan bersama tanpa harus dipungut biaya, dapat memperindah lingkungan dengan banyak pepohonan yang ada, serta memberikan kontribusi yang besar terhadap semakin tingginya polusi seiring meningkatnya volume kendaraan. Selama ini RTH publik telah dirasakan kemanfaatannya oleh masyarakat di antaranya adalah taman, stadion dan lapangan, jalur hijau, dan hutan kota. Satu hal penting tentang alasan persepsi mereka baik, walaupn baru sekelompok kecil anggota masyarakat, tetapi jelas bahwa faktor keuntungan yang dapat dimanfaatkan dan dirasakan tanpa pengeluaran biaya.

Kondisi pengetahuan dan persepsi masyarakat secara umum pada kategori rendah, merupakan akibat keterbatasan penyebarluasan informasi. RTRW dan RDTR. Namun sebenarnya pihak Pemerintah Daerah Kabupaten Temanggung sendiri telah memiliki web resmi pemerintah, yang memuat berbagai informasi UU, PP maupun Perda dan juga RTRW, yang berhubungan dengan perkembangan kawasan perkotaan dan perdesaan. Keberadaan web tersebut selain memuat berbagai informasi kebijakan publik, yang dapat dilihat dan dibaca online oleh masyarakat luas untuk dapat mengetahui, mempersepsi dan berpartisipasi secara tidak langsung dalam pelaksanaan RTRW dan RDTR. Namun demikian sebagai media informasi untuk sosialisasi UU, PP, Perda bagi anggota masyarakat Temanggung secara luas masih terbatas, mengingat akses internet baru digunakan oleh sebagian kecil anggota masyarakat. Dalam kenyataannya, walaupun telah dilegalisasi dan disosialisasikan mengenai RTRW dan RDTR, kenyataannya masih sulit bagi masyarakat secara komunal mampu berpartisipasi aktif dalam ruang permukiman mereka.

\section{2). Peranserta Masyarakat dalam Perencanaan dan Pemanfaatan Ruang Kawasan Permukiman}

Bappeda Kabupaten Temanggung (2015) menjelaskan tentang peranserta masyarakat dalam penataan ruang dilakukan pada tahap (a) perencanaan, (b) pemanfaatan ruang; dan (c) pengendalian pemanfaatan ruang. Seharusnya, bentuk peranserta masyarakat dalam perencanaan tata ruang meliputi saran, pendapat, dan masukan, antara lain tentang (1) persiapan penyusunan RDTR, (2) penentuan arah pengembangan wilayah, (3) pengidentifikasian potensi dan masalah pembangunan wilayah, (4) perumusan konsepsi RDTR, dan (5) penetapan RDTR. Di samping itu bentuk peranserta terwujud dalam kerja sama Pemerintah Daerah dengan unsur masyarakat dalam perencanaan tata ruang. Namun demikian dalam kenyataannya peranserta masyarakat yang terwujud ke dalam kegiatan tersebut belum dilakukan masyarakat, karena wujud rencanaannya sudah ada dalam wujud dokumen, yang disusun oleh Bappeda dan Pemerintah Daerah, hingga saat penelitian ini belum ditetapkan dan disosialisasikan.

Beberapa informan dari Bappeda dan Pemda Kabupaten Temanggung menuturkan, bahwa RTRW dan RDTR sudah tersedia. Namun hingga tahun 2014/2015 dokumen tersebut masih dalam proses revisi beberapa ketidaktepatan, ketidak sesuaian, dan beberapa kesalahan. Ditinjau dari segi pemanfaatan ruang yang ada di Kecamatan Temanggung memang masih didominasi pemanfaatan sektor pertanian, dengan penggunaan lahan utama yang ada di kecamatan tersebut merupakan lahan pertanian. Hal tersebut dikarenakan lingkungan fisik daerah yang masih banyak dipengaruhi oleh keberadaan gunungapi yang berada dekat dari lokasi tersebut. Keberadaan gunungapi tersebut mengakibatkan lahan yang terdapat di daerah ini tergolong subur dan ketersediaan air melimpah. Hal tersebut yang menyebabkan total produksi pertanian dari Kecamatan Temanggung termasuk tinggi. Kondisi kesuburan tanah yang tersedia, pada awalnya merupakan daya tarik penduduk untuk bermukim dengan kegiatan utama pada sektor pertanian, yang selanjutnya berkembang ke non pertanian terutama perdagangan, yang mengarah ke terbentuknya kawasan permukiman perkotaan, dan kehidupan kekotaan seperti terlihat hingga saat ini.

Pemanfaatan ruang atau kawasan untuk permukiman oleh warga masyarakat sebagai tempat tinggal menetap sudah cukup padat. Persebarannya bersifat mengelompok, namun secara umum tersebar dengan pola memanjang jalur transportasi. Kawasan permukiman di daerah ini masih banyak yang berada dekat dengan lahan pertanian. Hal tersebut menandakan bahwa penataan ruang oleh masyarakat setempat merupakan strategi yang dimaksudkan untuk mempermudah masyarakat dalam mencapai tempat pekerjaan terutama lahan pertanian. Namun demikian ke arah pusat pelayanan pemeritahan dan jasa terjadi pemadatan bangunan rumah tempat 
tinggal maupun bangunan rumah non permukiman terutama di pusat ibu kota Kabupaten Temanggung.

Pemanfaatan ruang untuk kawasan permukiman merupakan salah satu wujud nyata peranserta masyarakat secara langsung dalam membentuk dan menata ruang dan lingkungannya. Kawasan permukiman di di daerah kecamatan ini berisi berbagai prasarana dan sarana permukiman, antara lain sarana hunian atau perumahan, jaringan jalan, drainase, pengelolaan limbah, pengelolaan sampah, fasilitas umum, dan fasilitas sosial. Dalam bahasan ini lebih menekankan pada objek-objek tersebut baik di kawasan permukiman pusat kota, dan kawasan kota pinggiran, terutama di Kelurahan Temanggung dan Kelurahan Kowangan.

\section{3). Peranserta Masyarakat secara Langsung dalam Pemanfaatan Ruang Kawasan Permukiman}

\section{a. Pemanfaatan Ruang untuk Bangunan Rumah}

Bahasan kondisi bangunan dan status penguasaannya, mengungkap tipe bangunan rumah, kualitas menurut kondisi permanensi bangunan rumah tempat tinggal. Permanensi bangunan rumah dapat ditinjau berdasarkan pada dapat atau tidaknya bangunan rumah tersebut dipindahkan. Permanensi rumah dibagi ke dalam tiga tipe, permanen, semi permanen, dan tidak permanen. Selain itu permanensi juga didasarkan pada ukuran bahan yang digunakan untuk membangun bangunan rumah. Padau mumnya bangunan rumah permanen cenderung mempunyai kualitas yang lebih baik dibandingdengan bangunan rumah non permanen. Bahasan selanjutnya tentang kondisi bangunan rumah yakni diungkap tentang asal dan status pemilikan lahan dan bangunannya (Tabel 9.).

Permanenitas bangunan rumah adalah salah satu wujud ukuran kualitas perumahan, yang diukur berdasarkan pada dapat atau tidak dapatnya bangunan rumah tersebut dipindahkan. Selain itu permanenitas juga barkaitan dengan bahan-bahan yang digunakan untuk membangun rumah. Pada umumnya rumah permanen cenderung memiliki kualitas yang lebih baik dibanding dengan rumah non permanen. Bangunan rumah permanen dibangun dengan bahanbahan bangunan yang lebih kuat. Dalam menilai permanenitas dinding menjadi acuan utama. Bangunan rumah permanen cenderung memakai dinding batu bata, sedangkan rumah semi permanen dan non permanen menggunakan dinding kayu atau bahan lain yang ringan, dan dapat dipindahkan. Hasil penelitian menunjukkan (Tabel 9.) bahwa sebagian terbesar $(90 \%)$ bangunan rumah permanen berada di daerahpusat Kota Temanggung. Demikian pula di daerah pinggiran kota, jumlah bangunan rumah permanen cukup dominan (67\%), tetapi lebih sedikit proporsinya dari pada di pusat kota. Hal tersebut dimungkinkan sebagai akibat perbedaan kehidupan sosial ekonomi masyarakatnya yang berbeda.

Tabel 9. Komposisi Rumah Tangga Menurut Beberapa Aspek Bangunan Rumah

\begin{tabular}{|c|c|c|c|c|c|}
\hline \multirow[t]{3}{*}{ No } & \multirow{3}{*}{$\begin{array}{r}\text { Lokasi } \\
\text { Permukiman } \\
\text { Komponen } \\
\text { Tipe } \\
\text { Bangunan }\end{array}$} & \multicolumn{4}{|c|}{ Kawasan Permukiman } \\
\hline & & \multicolumn{2}{|c|}{ Pusat Kota } & \multicolumn{2}{|c|}{ Pinggiran Kota } \\
\hline & & $\begin{array}{l}\text { Juml } \\
\text { ah }\end{array}$ & Persen & Jumlah & Persen \\
\hline 1. & Bertingkat & 16 & 35,5 & 4 & 10,0 \\
\hline \multirow[t]{2}{*}{2.} & $\begin{array}{l}\text { Tidak } \\
\text { bertingkat }\end{array}$ & 28 & 64,5 & 32 & 90,0 \\
\hline & $\begin{array}{l}\text { Total } \\
\text { Kualitas } \\
\text { Permanensi } \\
\text { Bangunan }\end{array}$ & 44 & 100,0 & 36 & 100,0 \\
\hline 1. & $\begin{array}{l}\text { Permanen } \\
\text { (Tidak dpt } \\
\text { dipindah) }\end{array}$ & 40 & 90,5 & 24 & 66,7 \\
\hline 2. & $\begin{array}{l}\text { Semi } \\
\text { permanen } \\
\text { (Sebagian dpt } \\
\text { dipindah) }\end{array}$ & 1 & 3,2 & 7 & 20,0 \\
\hline \multirow[t]{2}{*}{3.} & $\begin{array}{l}\text { Tidak } \\
\text { permanen } \\
\text { (Seluruhnya } \\
\text { dpt dipindah) }\end{array}$ & 3 & 6,4 & 5 & 13,3 \\
\hline & $\begin{array}{l}\text { Total } \\
\text { Kualitas } \\
\text { Lingkungan } \\
\text { Permukiman }\end{array}$ & 44 & 100,0 & 36 & 100,0 \\
\hline 1. & $\begin{array}{l}\text { Tinggi (Skor } \\
142-197)\end{array}$ & 30 & 67,77 & 10 & 27,77 \\
\hline 2. & $\begin{array}{l}\text { Sedang (Skor } \\
85-141)\end{array}$ & 13 & 29,03 & 25 & 69,44 \\
\hline \multirow[t]{2}{*}{3.} & $\begin{array}{l}\text { Rendah (Skor } \\
28-84 \text { ) }\end{array}$ & 1 & 3,2 & 1 & 2,77 \\
\hline & $\begin{array}{l}\text { Total } \\
\text { Kondisi } \\
\text { Bangunan }\end{array}$ & 44 & 100,0 & 36 & 100,0 \\
\hline 1. & $\begin{array}{l}\text { Baik (rusak } \\
<10 \% \text { ) }\end{array}$ & 41 & 93,5 & 32 & 90,0 \\
\hline 2. & $\begin{array}{l}\text { Rusak ringan } \\
(10-20 \%)\end{array}$ & 2 & 6,5 & 4 & 10,0 \\
\hline Tot & & 44 & 100,0 & 36 & 100,0 \\
\hline
\end{tabular}

Sumber: Analisis Data Primer, 2016.

Kerusakan bangunanrumahsebenarnya dapat dibagi ke dalam empat kategori, yaitu baik (tidak rusak), rusak sedang, rusak ringan, dan rusak berat. Kategori baik jika tidak ada kerusakan pada bangunan rumah tersebut, rusak ringan jika terdapat sedikit kerusakan, kategori rusak sedang jika kerusakan cukup banyak, dan kategori rusak berat jika banyak bagian bangunan rumah yang rusak. Bagian-bagian rumah tersebut terutama dinding, 
pintu, jendela, dan atap. Namun demikian berdasarkan pada hasil penelitian (Tabel 9.) wilayah pusat kota dan pinggiran kota mempunyai kecenderungan sama yaitu sebagian besar $(>90 \%)$ bangunan rumah dalam keadaan baik.

Berdasar ketiga aspek komponen bangunan tersebut pada hakekatnya menunjukkan, bahwa sebagian besar anggota masyarakat secara keruangan (di pusat kota maupun pinggiran kota Temanggung), secara langsung dan tidak langsung telah berperan aktif dalam mewujudkan sebagian lingkungan yang sehat di kawasan permukiman mereka. Beberapa fakta peran aktif mereka dimungkinkan sebagai akibat rasa tanggung jawab yang besar, karena status penguasaan bangunan yang tentunya lebih kuat.

\section{b. Status Penguasaan Ruang dan Bangunan} Perumahan

Bahasan status penguasaan ruang yang dimanfaatkan untuk bangunan perumahan, dimaksudkan untuk menunjukkan hak penghuni atas lahan dan bangunannya. Status kepemilikan lahan dan bangunan rumah berhubungan erat dengan tingkat ekonomi dan sosial pemilik rumah tersebut. Berdasarkan pada hasil analisa data lapangan dapat dinyatakan bahwa sebagian besar masyarakat $(>70 \%)$ menempati bangunan rumah berstatus sebagai milik sendiri (Tabel 10.). Namun demikian masih terdapat masyarakat yang menghuni lahan dan bangunan rumah milik orang tuanya.

Tabel 10. Komposisi Masyarakat menurut Status Penguasaan dan Asal Lahan dan Bangunan Perumahan

\begin{tabular}{|c|c|c|c|c|c|}
\hline \multirow{3}{*}{$\begin{array}{c}\mathbf{N} \\
\mathbf{o}\end{array}$} & \multirow{3}{*}{$\begin{array}{c}\text { Lokasi } \\
\text { Permukiman } \\
\text { Komponen } \\
\text { Status } \\
\text { Pemilikan } \\
\text { Bangunan } \\
\text { Rumah }\end{array}$} & \multicolumn{4}{|c|}{ Kawasan Permukiman } \\
\hline & & \multicolumn{2}{|c|}{ Pusat Kota } & \multicolumn{2}{|c|}{$\begin{array}{c}\text { Pinggiran } \\
\text { Kota }\end{array}$} \\
\hline & & $\begin{array}{r}\text { Ju } \\
\text { mlah }\end{array}$ & $\begin{array}{c}\text { Pers } \\
\text { en }\end{array}$ & $\begin{array}{c}\text { Juml } \\
\text { ah }\end{array}$ & $\begin{array}{c}\text { Pers } \\
\text { en }\end{array}$ \\
\hline 1. & Milik Sendiri & 33 & 74,2 & 31 & 86,7 \\
\hline 2. & Sewa & 1 & 3,2 & 0 & 0,0 \\
\hline 3. & Kontrak & 4 & 9,7 & 0 & 0,0 \\
\hline \multirow[t]{2}{*}{4.} & $\begin{array}{l}\text { Milik Orang } \\
\text { Tua }\end{array}$ & 6 & 12,9 & 5 & 13,3 \\
\hline & $\begin{array}{l}\text { Total } \\
\text { Asal Lahan } \\
\text { yang } \\
\text { Dikuasai }\end{array}$ & 44 & 100,0 & 36 & 100,0 \\
\hline 1. & $\begin{array}{l}\text { Membeli } \\
\text { Lahan dan } \\
\text { Rumah }\end{array}$ & 13 & 9,1 & 4 & 10,0 \\
\hline 2. & $\begin{array}{l}\text { Membeli } \\
\text { Lahan }\end{array}$ & 7 & 6,1 & 20 & 56,7 \\
\hline 3. & Warisan & 18 & 41,9 & 12 & 33,3 \\
\hline 4. & $\begin{array}{l}\text { Menyewa/Ko } \\
\text { ntrak }\end{array}$ & 6 & 2,9 & 0 & 0,0 \\
\hline \multicolumn{2}{|c|}{ Total } & 44 & 100 & 36 & 100 \\
\hline
\end{tabular}

Sumber: Analisis Data Primer, 2016.
Secara keruangan pemilikan lahan dan bangunan rumah antara kawasan permukiman pusat kota dan pinggiran kota memiliki kesamaan, yakni sebagianbesarrumahberstatushak milik, meskipun di pinggiran kota relatif lebih banyak daripada tengah kota. Sebagian lagi, bangunan rumah yang dihuni berstatus warisan dari orang tua, hanya sedikit yang berstatus sebagai penyewa. Mereka yang menghuni sebagai penyewa biasanya adalah pendatang, terutama di kawasan pusat kota, terutama mereka yang bekerja di pasar dan kantor yang berada dekat dengan permukiman tersebut. Pada umumnya mereka belum mampu memiliki rumah tempat tinggal di tengah kota, karena kondisi ekonomi mereka belum mencukupi.

Ditinjau dari aspek asal lahan yang ditempati (Tabel 10.), terdapat perbedaan pola dari cara perolehan lahan di Kota Temanggung. Perbedaan pola dipengaruhi oleh faktor sosial yakni di kawasan permukiman pusat kota masih terdapat banyak penduduk asli, sehingga masih banyak pemilikan lahan berasal dari warisan, sedangkan di pinggiran kota banyak ditempati pendatang yang awalnya membeli lahan untuk kemudian didirikan bangunan rumah tempat tinggal mereka. Kenyataan tersebut di atas terdukung fakta bahwa di kawasan pusat kota yang terbanyak (42\%) berupa lahan dan bangunan dari warisan, namun di pinggiran kota sebagian besar masyarakat $(56,7 \%)$ justru memperoleh lahan hasil dari pembelian. Kenyataan tersebut menunjukkan bahwa kawasan pinggiran kota merupakan perkembangan kawasan pusat kota, yang ditengarai oleh banyaknya kasus jual beli lahan. Hal ini akibat dari masih tersedianya lahan dengan harga yang lebih murah dari pada di kawasan pusat kota

\section{c. Peranserta Masyarakat dalam Pemanfaatan Ruang Kawasan untuk Fasilitas Permukiman}

Fasilitas permukiman berupa prasarana dan sarana yang terdapat di kawasan permukiman ini merupakan perwujudan salah satu peranserta masyarakat dalam memanfaatkan dan mengelola lingkungan permukiman mereka. Beberapa fasilitas lingkungan permukiman di kawasan ini telah lama disediakan masyarakat, baik secara swadaya maupun atas bantuan subsidi dana beberapa program pemerintah dari waktu-ke waktu, telah membentuk struktur ruang kota atas dasar kearifan lokal swadaya masyarakat. Oleh karenanya meskipun RTRW dan RDTR tahun 2011/2012 masih dalam proses penyelesaian revisinya, sebenarnya secara swadaya masyarakat telah berperanserta pelaksanaan sebagian RTRW dan RDTR. Beberapa prasarana dan sarana yang telah tersedia antara lain fasilitas jalan, drainase, pengelolaan limbah, fasilitas umum dan fasilitas, sosial. 


\section{(1) Fasilitas Transportasi}

Aksesibilitas adalah tingkat kemudahan suatu lokasi yang dapat dijangkau oleh berbagail okasi lain (Soefat,1997). Salah satu ukuran aksesibitas adalah fasilitas transportasi antara lain jalur jalan. Jalur jalan yang tersedia di kawasan permukiman, hingga saat ini mampu mendukung mobilitas penduduk, mulai dari kondisi jalan yang sebagian besar kualitasnya dalam kondisi baik. Dengan mengacu pada SNI 03-1733-2004, hasil analisis komparatif berdasarkan pada baku perencanaan lingkungan perkotaan versi SNI dengan kondisi nyata lapangan, dapat ditunjukkan bahwa prasarana jalan telah memenuhi baku dimensi minimal ideal tersebut sebagai berikut.

1) Jalan lokal sekunder I, lebar minimum dengan dua jalur adalah 5,5-6,0 $\mathrm{m}$ dan lebar bahu jalan $1,0-1,5 \mathrm{~m}$;

2) Jalan lokal sekunder II, lebar badan jalan 4,55,5m dengan lebar bahu jalan 0,75-1m;

3) Jalan lokal sekunder III lebar badan jalan 4,0-5,5 $\mathrm{m}$ dengan lebar bahu jalan 0,75-m;

4) Jalan lingkungan I lebar badan jalan 3,5 - $4 \mathrm{~m}$ dengan lebar bahu $0,5-0,75 \mathrm{~m}$, yang dapat dilengkapi dengan trotoar untuk pejalan kaki dan fasilitas orang cacat;

5) Jalan lingkungan II lebar badan jalan $3-3,5 \mathrm{~m}$ dengan lebar bahu $0,5-0,75 \mathrm{~m}$ serta trotoar apabila diperlukan.

Kondisi jalan-jalan tersebut mampu mendukung mobilitas penduduk sampai daerah pinggiran kota. Mengenai kondisi jalur jalan sebagai prasarana transportasi di kawasan ini dibahas keterkaitannya dengan kualitas jalan, yang menyangkut jenis material bahan yang digunakan, dan lebar jalan yang tersedia. Kualitas tersebut mendukung kekuatan dan kemampuan lalu lintas kendaraan menjangkau kawasan permukiman, yang didasarkan pada asumsi, bahwa semakin tinggi kualitas jalur jalan maka keterjangkauan bangunan rumah beserta kawasan permukimannya semakin mudah. Material bahan bangunan jalan yang terdapat di kawasan permukiman secara keruangan bervariasi antara kawasan di pusat kota dengan yang terdapat di kawasan pinggiran kota.

Hasil penelitian lapangan dapat dilihat pada Tabel 11. yang mencakup jenis jalan, dan lebar jalan di kawasan permukiman pusat Kota maupun pinggiran Kota Temanggung. Dalam pengukuran di lapangan jika ditemukan bangunan rumah yang memiliki dua sisi depan, maka jenis material bahan jalan yang diambil adalah jalan depan rumah yang kualitasnya paling baik. Kenyataan lapangan menunjukkan bahwa sebagian besar $(>60 \%)$ rumah tinggal (Tabel 11.), baik di pusat kota maupun di pinggiran kota berada dan berhadapan dengan tepi atau pinggir jalan cor beton. Hal ini karena cukup banyak jalur jalan berupa gang kecil, sehingga yang paling mungkin digunakan untuk memperkuat jalan adalah cor beton. Sementara itu jalan aspal terdapat pada lokasi berdekatan dengan rumah mukim yang letaknya memang di pinggir jalan utama antarkota. Kenyataan jalan aspal lebih banyak pada bangunan rumah yang dihuni masyarakat di pusat kota $(32,3 \%)$ dari pada masyarakat di pinggiran kota $(16,7 \%)$.

Tabel 11. Komposisi Penduduk menurut Kualitas Jalan menuju Rumah Tempat Tinggal

\begin{tabular}{|c|c|c|c|c|c|}
\hline \multirow[t]{2}{*}{$\begin{array}{c}\mathbf{N} \\
\mathbf{0}\end{array}$} & \multirow{2}{*}{$\begin{array}{l}\begin{array}{c}\text { Lokasi } \\
\text { Permukim } \\
\text { an }\end{array} \\
\text { Jenis } \\
\text { Jalan }\end{array}$} & \multicolumn{2}{|c|}{ Pusat Kota } & \multicolumn{2}{|c|}{$\begin{array}{l}\text { Pinggiran } \\
\text { Kota }\end{array}$} \\
\hline & & $\underset{\text { humla }}{\text { Jum }}$ & $\begin{array}{r}\text { Pe } \\
\text { rsen }\end{array}$ & $\begin{array}{r}\text { Ju } \\
\text { mlah }\end{array}$ & $\begin{array}{r}\text { Pe } \\
\text { rsen }\end{array}$ \\
\hline 1. & Aspal & 14 & 32,3 & 6 & 16,7 \\
\hline 2. & Cor beton & 27 & 61,3 & 28 & 76,7 \\
\hline 3. & $\begin{array}{l}\text { Batu } \\
\text { terasah }\end{array}$ & 3 & 6,4 & 1 & 3,3 \\
\hline \multirow[t]{4}{*}{4.} & Tanah & 0 & 0,0 & 1 & 3,3 \\
\hline & Total & 44 & 100,0 & 36 & 100,0 \\
\hline & Lebar & Jumla & $\mathbf{P e}$ & Ju & Pe \\
\hline & Jalan (m) & $\mathbf{h}$ & rsen & mlah & rsen \\
\hline 1. & $\begin{array}{l}\text { Lingkunga } \\
\text { n III }(<3)\end{array}$ & 14 & 32,3 & 12 & 33,3 \\
\hline 2. & $\begin{array}{l}\text { Lingkunga } \\
\mathrm{n} \text { II }(3-3,5)\end{array}$ & 21 & 48,4 & 18 & 50,0 \\
\hline 3. & $\begin{array}{l}\text { Lingkunga } \\
\text { n I }(3,5- \\
>5)\end{array}$ & 0 & 0,0 & 5 & 13,3 \\
\hline 4. & $\begin{array}{l}\text { Lokal ( } \geq \\
5)\end{array}$ & 9 & 19,3 & 1 & 3,4 \\
\hline \multicolumn{2}{|c|}{ Total } & 44 & 100,0 & 36 & 100,0 \\
\hline
\end{tabular}

Sumber: Analisis Data Primer, 2016.

Berdasarkan Tabel 12. dapatditunjukkan bahwa sebagianbesarrumahdipusatkota $(61,3 \%)$ tidakmempunyaipohonpelindung.Keberadaan pohon pelindung di pekarangan sebagian terbatas, karena letak rumah yang berada di pinggir jalan besar, namun masih mendapat peneduhan dari pohonpohon pelindung jalan yang ditanam oleh pemerintah kota di beberapa bagian sepanjang penggal jalan. Bangunan rumah-rumah dikawasan permukiman pinggiran kota relatif mempunyai lebih $(58,3 \%)$ banyak pohon pelindung daripada di pusat kota, karena masih adanya ketersediaan ruang atau lahan yang cukup untuk menanam pohon.

Tabel 12. Komposisi Penduduk Menurut Keberadaan Pohon Pelindung di Jalan dan Pekarangan Dekat Rumah

\begin{tabular}{llrrrr}
\hline No & $\begin{array}{c}\text { Keberadaan } \\
\text { Pohon } \\
\text { Pelindung }\end{array}$ & Jumlah & Persen & Jumlah & Persen \\
\hline 1. & Banyak & 0 & 0,0 & 8 & 22,2 \\
2. & Sedikit & 17 & 38,7 & 13 & 36,1
\end{tabular}




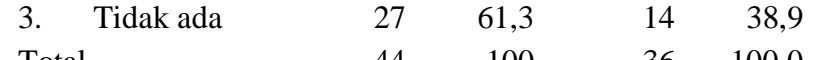

$\begin{array}{lllll}\text { Total } & 44 & 100 & 36 & 100,0\end{array}$

Sumber: Analisis Data Primer, 2016.

\section{(2) Fasilitas Pembuangan Limbah Cair dan Sampah}

Limbah merupakan salah satu masalah penting di perkotaan, mengingat kepadatan bangunan rumah dan ketersediaan lahan yang sempit. Limbah cair yang tidak terkelola dengan baik berpotensi mencemari lingkungan, yang dapat berakibat pada penurunan kualitas lingkungan rumah itu sendiri. Limbah cair berasal dari aktivitas rumah tangga setiap hari, baik itu berupa limbah yang berasal dari kamar mandi, limbah pencucian, maupun limbah cair dari dapur. Pengelolaan limbah cair yang biasa dilakukan, yakni disalurkan ke saluran limbah khusus ke tanki septik. Namun demikian alternatif lain meskipun tidak dibenarkan banyak di antara mereka menyalurkan limbah cair ke sungai, dan atau dibiarkan tergenang, sehingga meresap ke tanah ( Tabel 13).

Tabel 13. Komposisi Penduduk Menurut Cara Penanganan Limbah Rumah Tangga di Daerah Penelitian

\begin{tabular}{llcccc}
\hline N & Lokasi & \multicolumn{2}{c}{ Pusat Kota } & \multicolumn{2}{c}{ Pinggiran } \\
\cline { 3 - 6 } o & Pembuang & Jumla & Perse & Jumla & Perse \\
& an Limbah & h & n & h & n \\
\hline 1. & Septic Tank & 24 & 54,5 & 6 & 16,7 \\
2. & Kolam ikan & 0 & 0,0 & 4 & 11,1 \\
3. & Saluran & 20 & 45,5 & 25 & 69,4 \\
& selokan/ & & & & \\
& sungai & & & & \\
4. & Tempat & 0 & 0,0 & 1 & 2,8 \\
\multicolumn{2}{l}{ Total } & 44 & 100 & 36 & 100 \\
\hline
\end{tabular}

Sumber: Analisis Data Primer, 2016.

Lokasi pembuangan limbah merupakan salah satu wujud peranserta masyarakat dalam pemanfaatan ruang, khususnya untuk sarana pembuangan limbah dan mengelola kualitas lingkungannya. Keadaan di lapangan menunjukkan bahwa terdapatperbedaandalam pembuangan limbah antara masyarakat di pusat kota dengan di pinggiran kota. Sebagian besar masyarakat $(54,5 \%)$ di pusat kota membuang atau menyalurkaan limbahnya ke dalam septic tank, sedangkan sebagian besar masyarakat pinggiran kota $(69,4 \%)$ membuang atau menyalurkan limbah cair langsung ke selokan atau ke sungai. Hal ini disebabkan lokasi rumah tempat tinggal mereka terletak di pinggiran kota yang dekat dengan sungai.

Aspek pengelolaan sampah merupakan hal yang penting dalam penilaian kualitas suatu kawasan permukiman, karena setiap kegiatan rumahtangga setiap harinya pasti menghasilkan sampah, baik itu sampah organik (sampah dapur, sisa makanan), maupun sampah anorganik. Permukiman yang bersih dari sampah tentunya mempunyai kualitas yang baik. Pengelolaan sampah dilakukan dengan cara membuang sampah ke TPA, membakar, menimbun dalam tanah, atau membuang ke sungai. Peranserta masyarakat di kedua kawasan permukiman pusat Kota maupun pinggiran Kota, sudah cukup baik. Hasil penelitian tentang pengelolaan sampah menunjukkan bahwa semua anggota masyarakat membuang sampah mereka ke tempat penampungan sementara (TPS) yang sudah ditentukan, yang selanjutnya oleh petugaskebersihan kota diambil dan diangkut ke tempat pembuangan akhir sampah (TPA). Kenyataan ini menggambarkan adanya pengelolaan sampah yang baik di kawasan permukiman pusat kota maupun di kawasan permukiman pinggiran kota.

\section{(3) Fasilitas Drainase}

Fasilitas drainase berfungsi mengalirkan air di lingkungan bangunan rumah utama ketika terjadi hujan. Kondisi drainase yang tidak baik berpotensi dapat berakibat pada meluapnya air dan membanjiri rumah-rumah warga. Hal ini tentunya dapat berakibat pada penurunan kualitas bangunan rumah maupun kualitas lingkungan permukiman. Sebaliknya kualitas bangunan rumah dapat semakin baik bila kondisi drainase dapat berfungsi dengan sempurna, sehingga bangunan rumah tidak akan terncam genangan air. Drainase di kawasan permukiman kota ini, berupa parit atau saluran air kecil, yang terletak di pinggir jalan dan pinggir gang. Dalam kaitannya dengan peranserta masyarakat dalam pengelolaan drainase diukur pada saat turun hujan ada air yang menggenang atau tidak.

Tabel 14. Komposisi Penduduk Menurut Kondisi Drainase Perumahannya di Daerah Penelitian

\begin{tabular}{clcccc}
\hline No & Drainase & $\begin{array}{c}\text { Jumlah } \\
\text { Jumlah }\end{array}$ & Persen & Jumlah & Persen \\
\hline 1. & Menggenang & 2 & 3,0 & 2 & 6,6 \\
2. & $\begin{array}{l}\text { Mengalir } \\
\text { tidak lancar }\end{array}$ & 3 & 6,9 & 2 & 6,6 \\
$\begin{array}{l}\text { 3. } \\
\quad \begin{array}{l}\text { Mengalir } \\
\text { lancar }\end{array}\end{array}$ & 38 & 87,1 & 31 & 86,8 \\
\multicolumn{2}{l}{ Total } & 44 & 100,0 & 36 & 100,0 \\
\hline
\end{tabular}

Sumber: Analisis Data Primer, 2016.

Berdasarkan hasil penelitian lapangan (T abel 14.) secara umum bangunan rumah di Perkotaan Temanggung sudah dilengkapi saluran drainase, sehingga jika terjadi aliran air dari hujan atau dari sumber lain dapat mengalir lancar. Kenyataan tersebut terjadi dan terdapat di kawasan permukiman pusat kota dan di kawasan permukiman pinggiran kota. Di beberapa 
pekarangan bangunan rumah terdapat pula saluran drainase aliran air tidak lancar, karena letak rumah yang berada di pusat-pusat permukiman dan mempunyai ukuran saluran drainase sangatkecil, sehingga air tidak dapat mengalir dengan sempurna.

\section{(4) Fasilitas Rekreasi dan Pemanfaatan Ruang Terbuka Hijau}

Peranserta masyarakat dalam pemanfaatan ruang terutama untuk rekreasi dalam kota, adalah melakukan kegiatan menikmati keberadaan ruang terbuka hijau (RTH). Jenis RTH di Kecamatan atau Kota Temanggung, khususnya dibedakan menjadi RTH publik dan Ruang RTH privat. RTH publik merupakan ruang terbuka hijau yang dimiliki dan dikelola oleh pemerintah daerah kota atau kabupaten yang digunakan untuk kepentingan masyarakat secara umum, sedangkan RTH privat merupakan ruang terbuka hijau milik institusi tertentu atau perseorangan yang pemanfaatannya untuk kalangan terbatas, antara lain berupa kebun atau halaman rumah gedung milik masyarakat atau swasta yang ditanami tumbuhan. Hasil penelitian ini dapat menunjukkan bahwa RTH Privat lebih luas dari pada RTH Publik.

Dari persepsi masyarakat di kedua lokasi permukiman pusat kota maupun pinggiran kota, mengharapkan pemerintah mempertahankan dan memperluas RTH publik berupa taman kota maupun rekreasi, stadion, dan jalur hijau. Mereka merasa tidak terganggu dengan keberadaan ruang publik tersebut. Mereka justru mendapat manfaat dari adanya ruang publik, karena dapat dimanfaatkan sebagai tempat rekreasi keluarga, tempat olahraga, bahkan sebagai tempat berjualan untuk menambah penghasilan.

Selama ini, RTH publik di dua kawasan telah dimanfaatkan oleh masyarakat di antaranya taman, stadion, lapangan, jalur hijau, dan hutan kota. Namun masyarakat setempat masih mengeluhkan tentang beberapa fasilitas yang terdapat di taman yang kurang terawat, sehingga perlu adanya perawatan rutin serta perlu adanya penambahan pepohonan di sepanjang jalan agar jalan lebih sejuk, dan mampu mengurangi polusi dari asap kendaraan.

Harapan dari masyarakat bahwa pemerintah dapat memberikan ruang publik yang lebih, agar dapat dimanfaatkan secara umum karena saat ini ruang bermain untuk anak, ruang rekreasi keluarga, dan olahraga biasanya sudah semakin berkurang. Kondisi RTH publik yang ditanami dengan tanaman yang berkanopi lebar atau tumbuhan kayu yang besar, juga diperlukan untuk meminimalisir kerusakan lingkungan dari segi polusi dan kondisi cuaca di Kota Temanggung yang sudah tidak terlalu dingin seperti beberapa tahun yang lalu.

\section{Kesimpulan}

Berdasarkan hasil kajian dan pembahasan maka dapat disimpulkan, bahwa status daerah kecamatan sebagai ibukota kabupaten, belum sepenuhnya bersifat kekotaan. Hal ini disebabkan karakteristik kota secara morfologis maupun kehidupan sosioekonomis kekotaan masih lebih dominan di pusat kota, sedangkan di pinggiran kota meskipun secara morfologis berupa kota, tetapi masih didominasi kehidupan yang bersifat kedesaan.

Dalam kaitannya dengan keberadaan UUTR maupun RTRW di daerah kabupaten yang belum disosialisasikan secara intensif, berakibat pada beberapa aspek berikut.

- Pengetahuan dan persepsi masyarakat lokal, masih termasuk kategori rendah. Masyarakat pada umumnya belum merasakan manfaat adanya UUTR dan RTRW maupun RDTR, namun dengan kearifannya justru menganggap ruang yang tersedia sudah terbentuk dengan baik, dan merasa nyaman dengan kondisi saat ini.

- Peranserta masyarakat dalam pelaksanaan RTRW yang ada belum dilakukan, namun peranserta masyarakat dalam pemanfaatan dan pengendalian ruang secara umum telah terwujud, dalam bentuk pemanfaatan dan pengedalian ruang untuk kegiatan pertanian, permukiman, dan tempat fasilitas pelayanan sosial ekonomi dan budaya.

Peran masyarakat terkait dengan hak dan kewajiban masyarakat dalam pemanfaatan ruang dan pengendalian pemanfaatan ruang, tampak pada status penguasaan ruang tanah dan bangunan perumahan secara legal. Peranserta masyarakat dalam pengendalian pemanfaatan ruang kawasan permukiman ditunjukkan dari keterkaitan erat lokasi perumahan dengan beberapa fasilitas pengendali lingkungan seperti, pengelolaan limbah cair dan sampah, drainase, fasilitas umum berupa RTH.

\section{Saran}

Berdasarkan pada kesimpulan utama bahwa dalam kaitannya dengan keberadaan UUTR maupun RTRW di daerah kabupaten yang belum disosialisasikan secara intensif, maka seyogyanya pemerintah daerah sesegera mungkin melaksanakan beberapa hal berikut.

a. Sosialisasi UUTR dan RTRW serta RDTR untuk meningkatkan pengetahuan dan persepsi masyarakat lokal yang masih termasuk kategori rendah.

b. Dalam sosialisasi ketiga aspek tersebut perlu ditekankan pada percontohan konkrit tentang manfaat yang dapat dirasakan masyarakat secara langsung, dengan tekanan tetap mempertahankan kearifan lokal yang sudah dimiliki dan dinikmati masyarakat.

c. Peranserta masyarakat dalam pelaksanaan RTRW khususnya dalam usaha pengendalian pemanfaatan ruang untuk kegiatan pertanian, permukiman, dan tempat fasilitas pelayanan sosial ekonomi dan budaya, masih harus diarahkan pada usaha-usaha yang bersifat konservasi lingkungan. 
d. Peran masyarakat terkait dengan hak dan kewajiban dalam pemanfaatan ruang dan pengendalian pemanfaatan ruang, khususnya status penguasaan lahan dan bangunan perumahan perlu dilindungi sesuasi dengan hak asasi yang berlaku di daerah ini.

\section{DAFTAR PUSTAKA}

Anonimus, 2016, Daftar UMR dan UMK Jawa Tengah, dalam http://www.teskerja.com/ 2015/09/35-daftar-umk-jawa-tengah2016-2017.html. Diunduh September 2016.

Badan Pusat Statistik Kab. Temanggung, 2013. Kabupaten Temanggung Dalam Angka Tahun 2013. Temanggung: Badan Pusat Statistik Kab. Temanggung.

2015.

Kabupaten Temanggung Dalam Angka Tahun 2015. Temanggung: Badan Pusat Statistik Kab. Temanggung.

Bappeda Kab. Temanggung, 2015, Rencana Detil Tata Ruang Kawasan Strategis Kabupaten Temanggung Tahun 2015. Temanggung: Kantor Bappeda Kab. Temanggung.

Handiman, Rico. 2006. Kebijakan Nasional dalam Perencanaan Tata Ruang. Dalam Artikel Bakosurtanal, 08 Desember 2006.

Peraturan Pemerintah, 3 Desember 1996, PP No.69 Tahun 1996 tentang Pelaksanaan Hak dan Kewajiban, serta Bentuk dan Tata Cara Peran Serta Masyarakat dalam Penataan Ruang.

Ritohardoyo, Su., 2010. Partisipasi Masyarakat dalam Konservasi Sungai Bawahtanah di Desa Seropan Kabupaten Gunung Kidul, dimuat dalam Majalah Ilmiah Ulul Albab Vol. 14, Nomor 1, Januari 2010, halaman 1 - 11, Lembaga Penelitian Universitas Muhammadiyah Mataram tahun 2010.

Sekda Kab. Temanggung, 2012. Peraturan Daerah Kabupaten Temanggung No.1. Th. 2012 tentang Rencana Tata Ruang Wilayah Kabupaten Temanggung Tahun 20112031. Temanggung: Kantor Pemda Kab. Temanggung.

SNI 03-1733-2004, 2004. Tata cara perencanaan lingkungan perumahan di Perkotaan. Jakarta: Badan Standardisasi Nasional.

Soefat, 1997,

Undang-undang No. 24 Tahun 1992 tentang Penataan Ruang.

Undang-undang No. 26 Tahun 2007 tentang Penataan Ruang.
Undang-undang 32/2004 tentang Otonomi Daerah

Undang-undang Perlindungan dan Pengelolaan Lingkungan Hidup No. 32 Tahun 2009 pada Bab XI, Pasal 70.

UU Nomor 1 Tahun 2011 tentang Perumahan dan Kawasan Permukiman. 